
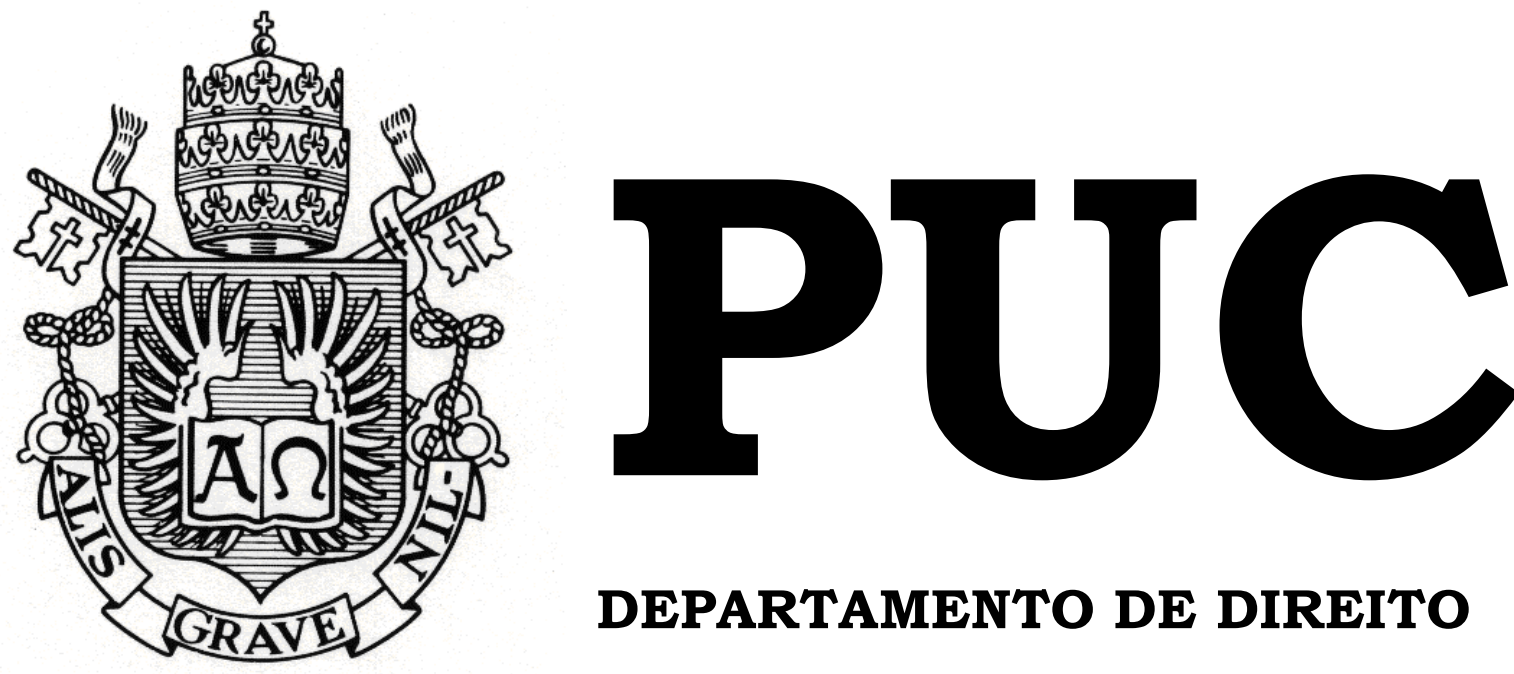

DEPARTAMENTO DE DIREITO

Da Propriedade aos Bens Comuns. por

Matteo Louis Raul Meirelles Theubet

Orientador: Alexandre Fabiano Mendes.

2013.2

PONTIFÍCIA UNIVERSIDADE CATÓLICA DO RIO DE

JANEIRO

RUA MARQUÊS DE SÃO VICENTE, 225 - CEP 22453-900

RIO DE JANEIRO - BRASIL 


\title{
Da propriedade aos Bens
}

\section{Comuns.}

\author{
por
}

Matteo Louis Raul Meirelles Theubet

Monografia apresentada

ao Departamento de

Direito da Pontificia

Universidade Católica do

Rio de Janeiro (PUC-Rio) para a obtenção do Título de Bacharel em Direito.

Orientador(a): Alexandre Fabiano Mendes. 


\section{Agradecimentos.}

Agradeço primeiramente minha família, de "perto" e de "longe", por terem me proporcionado, através de seus ensinamentos e de suas trajetórias de vida, o verdadeiro valor das coisas. Todo o amor, o carinho, e a dedicação em suas conquistas me permitiram seguir em frente, e foram essenciais para a minha trajetória. Sou um privilegiado, e agradeço do fundo do coração por tudo que fizeram por mim!

Queria agradecer também a todos que fizeram parte desta trajetória, os grandes amigos que ganhei nestes cinco anos de faculdade, e também aqueles de longa data. Em especial, queria agradecer a "maior das minhas amigas", minha companheira, meu amor, Stéphanie, por toda a paciência e ternura que me deram forças para alcançar meus objetivos. Obrigado por me fazer crescer, todo dia.

Ao eterno "chefinho", orientador, amigo e camarada de lutas Alexandre F. Mendes, sem o qual não chegaria onde estou. Sua sensibilidade, seu profissionalismo e sua paixão pelos outros me dão a certeza de que um mundo mais justo é possível.

Também gostaria de agradecer a dois "grandes grupos", o eterno e jamais esquecido "Núcleo de Terras", cujas experiências vou carregar para o resto da vida. Ao "Terras e Lutas", cujas amizades e horizontes de luta me inspiram a seguir caminhando...

Aos guerreiros André, Jane, Altair, Inalva e Jorge, não tenho palavras para expressar minha gratidão, seus exemplos de vida falam por si só...

"Je est un autre".

-Rimbaud. 


\section{Sumário}

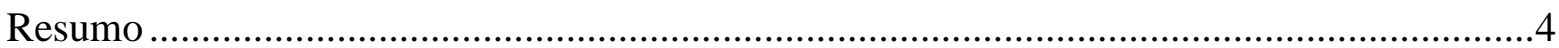

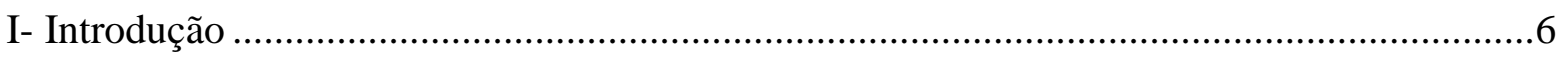

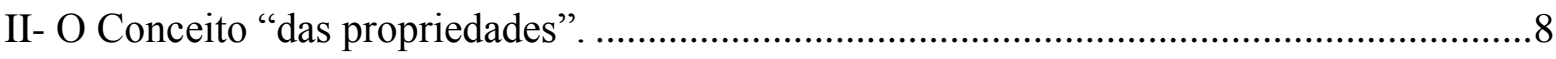

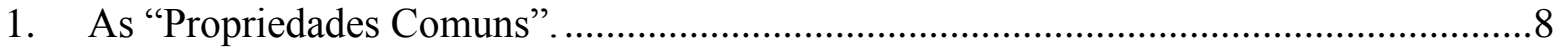

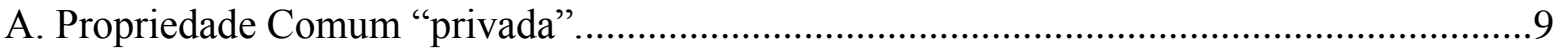

B. Propriedade Comum Pública. .............................................................................................13

2. O Binômio Publico X Privado na propriedade moderna.....................................................15

III. Um retorno às origens históricas e ideológicas da propriedade moderna. ..................18

A. A propriedade como "construção de mentalidades".......................................................19

B. Dominium sui: a interiorização da propriedade no âmbito do sujeito..............................22

C. O contexto histórico da propriedade moderna...............................................................24

D. O "État-providence" e a função social da propriedade....................................................31

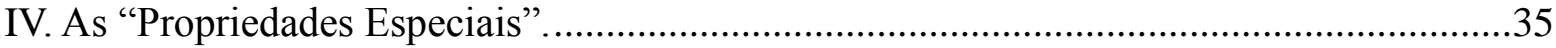

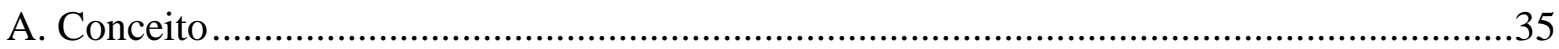

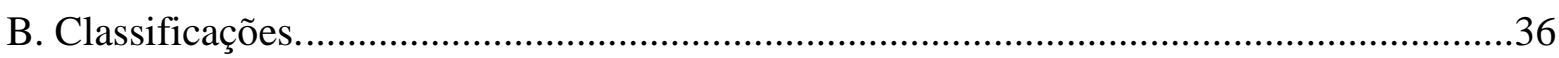

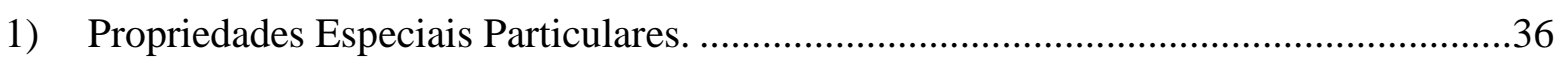

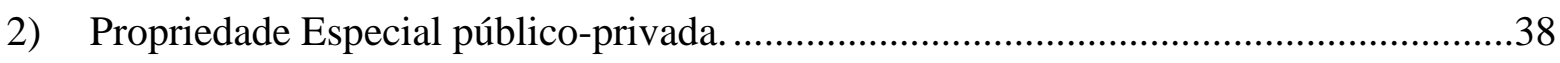

3) Propriedades Especiais Coletivas: patrimoniais (étnicas) e extra-patrimoniais

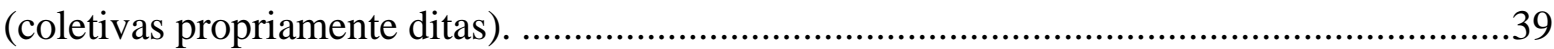

V. "As propriedades" e a manutenção do binômio público-privado. .......................................44

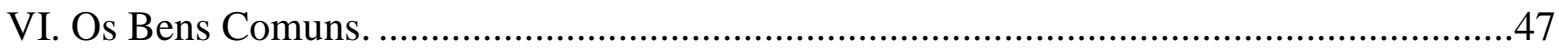

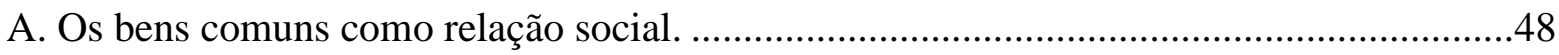

B. Os Bens Comuns como elementos essenciais a consecução dos direitos

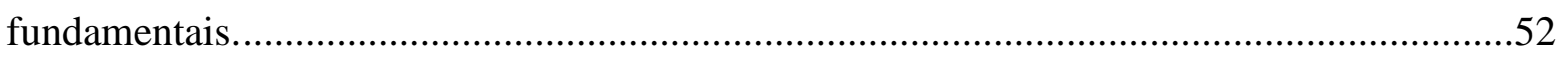

C. Os Bens Comuns e o "comum” como poder político.....................................................56

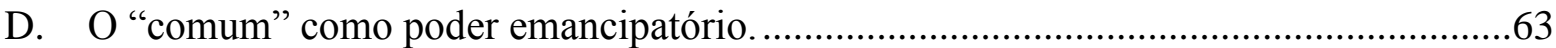

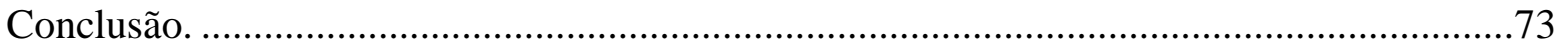

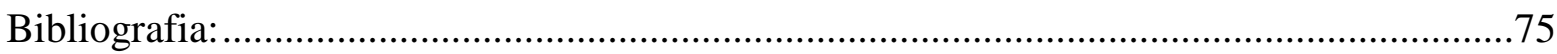




\section{Resumo}

O presente trabalho tem por objetivo trilhar um caminho: uma jornada que nos leve da propriedade aos bens comuns. A concentração de terras, a desigualdade social, os problemas políticos no Brasil são o reflexo de uma desigualdade que se perpetua por todas as esferas de poder, sejam elas políticas, econômicas ou sociais. $\mathrm{Na}$ busca de uma melhor compreensão destes problemas, de identificar entre eles um elemento comum, a propriedade surge como o cerne de todas estas disputas. Temos tendência em confundir e a considerar a propriedade sob seu aspecto privado, como sendo um bem corpóreo, individualizado e sujeito à vontade do proprietário, que exerce sob este bem uma gama de poderes que lhe são inerentes. A propriedade, no entanto, não se restringe a este conceito limitado.

Repensar a propriedade significa repensar o núcleo no qual se inserem uma série de "situações reais": a propriedade é forma organizadora da vida cotidiana, condiciona a maneira com a qual nos relacionamos com outrem e com os objetos que nos cercam; a propriedade molda nossa percepção de mundo. Buscar compreender as razões do "absolutismo" da propriedade nos leva a uma evidência: a de que esta "confusão", este reducionismo ao qual condicionamos a propriedade é em verdade fruto de uma "mentalidade" construída. Leva-nos a evidência de que essa condição é proposital.

Nesta jornada que empreenderemos, buscaremos compreender as bases na qual foram instituídas estas premissas sobre a propriedade, destrinchar os aspectos deste conceito tão vasto, estudar suas recentes transformações e entender melhor suas limitações.Buscaremos nos bens comuns uma alternativa, um outro caminho que fuja destas limitações e que apresente um novo horizonte de valores, de igualdade e de justiça social. 
Em meio à complexidade e a sensibilidade que demanda o tema, avançamos graças a uma certeza: a de que o caminho que escolhemos é um caminho de emancipação, um caminho que nos levará a liberdade.

Palavras chave: Direito Civil. Propriedade. Construção histórica do conceito moderno de propriedade. Propriedades pós-modernas. Bens Comuns. 


\section{I- Introdução}

A propriedade é um dos conceitos mais complexos existentes no direito. Em termos sociais, a propriedade está diretamente ligada às estruturas político-econômicas da sociedade, e em termos conceituais, envolve em sua essência a relação do homem com as coisas. Conceitos tão subjetivos possuem, naturalmente, uma dificuldade de serem sintetizados em uma única definição, que abarque em sua plenitude a pluralidade de meios aos quais a propriedade está intimamente ligada.

Algo, porém, parece inato ao conceito de propriedade. Nos dizeres de Orlando Gomes:

"é inafastável o reconhecimento da historicidade do conceito do direito de propriedade, pois, sem embargo da projeção que emerge das fontes clássicas e se lança para o direito contemporâneo, o contexto histórico revela planos e vicissitudes irredutíveis a um conceito único".

Se estamos nos propondo a começar uma jornada, é fundamental estabelecermos as bases das quais partiremos. Para discutirmos a propriedade, necessitamos em um primeiro momento entendê-la, conceituála, e definir quais elementos essenciais merecem nossa atenção. As peculiaridades da propriedade, como veremos, nos darão elementos que ajudarão a compreender as questões relativas às bases históricas em que a propriedade moderna foi pensada.

Se a propriedade é cambiável, e relaciona-se com diversos institutos que dificultam a sua conceituação, a historicidade do conceito de propriedade é um elemento chave para compreendermos as questões que modularam este conceito, saindo do plano puramente teórico para compreender a essência das questões em disputa. Através desta análise histórica se buscará demonstrar, no âmbito jurídico ocidental, que tal conceito adquiriu um "absolutismo" que simplifica e transforma a própria

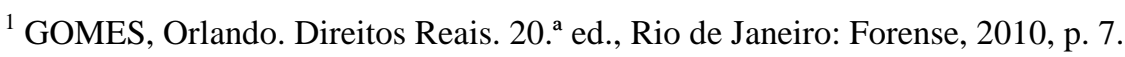


relação do homem com a propriedade. Por meio desta análise histórica, e do estudo do surgimento do conceito de propriedade, o presente trabalho buscará não contrapor dois institutos, mas apresentar nos bens comuns uma alternativa a este modelo jurídico imposto.

Os bens comuns são tratados por diversos autores, cada um atribuindo-lhes uma esfera de importância que buscaremos destacar, e construir através destes diferentes olhares um caminho que nos levará a uma emancipação do absolutismo imposto pela propriedade.

Repensar a propriedade é primordial para a construção de um pensamento que foge dos dogmas de uma solução histórica dominante, e o ponto de partida para se pensar uma sociedade pautada em relações e valores distintos daqueles existentes atualmente. 


\section{II - O Conceito "das propriedades".}

Se nos propusemos a elaborar um debate acerca da propriedade é importante, em um primeiro momento tentar conceituar o objeto em debate. Optamos por dar especial atenção para o que, nas palavras de José Isaac Pilati, aparece como o novo paradigma da propriedade "pós-moderna". Se não podemos afirmar que existe um conceito único de propriedade devemos no entanto, buscar esclarecer as diferentes facetas "das propriedades" que surgiram na "pós modernidade".

Para tanto, reportar-nos-emos a uma subdivisão proposta por Pilati, a qual se divide em duas categorias e nas quais se enquadram as propriedades "pós-modernas": a propriedade comum e as propriedades especiais. Ambas as categorias dividem-se não só pela definição e pela finalidade, mas também quanto ao titular, ao objeto, ao exercício e a tutela que as compõe.

Em um primeiro momento, a título de abordagem metodológica, colocaremos em evidência os conceitos abrangidos pela primeira categoria de classificação proposta, a das propriedades comuns, a fim de estabelecer em que medida estas se aproximam de sua acepção originária, a "Propriété Napoléonienne", calcada em uma "dominialidade proprietária individualista". O comum aqui, não deve ser confundido com os "bens comuns", os quais serão abordados na segunda parte do presente trabalho, mas relaciona-se apenas ao conceito antagônico proposto por Pilati, a de que a "propriedade comum" não é "propriedade especial".

\section{As "Propriedades Comuns".}

As propriedades comuns, em oposição às propriedades especiais que estudaremos mais adiante, dividem-se em duas categorias: a propriedade comum privada, e a propriedade comum pública. Estudaremos a seguir seus conceitos, realizando um paralelo com as definições dadas por diversos autores presentes na doutrina pátria. 


\title{
A. Propriedade Comum "privada".
}

A propriedade Comum rege-se pelo art. 1228 do Código Civil de 2002, que estipula:

"Art. 1.228. O proprietário tem a faculdade de usar, gozar e dispor da coisa, e o direito de reavê-la do poder de quem quer que injustamente a possua ou detenha."

Tal forma de propriedade baseia-se na lógica da "dominialidade proprietária individualista”, e encontra nas palavras de Pilati definição sucinta:

\begin{abstract}
"Estrutura-se e classifica-se pelas categorias tradicionais: móvel e imóvel, plena e restrita, perpétua e resolúvel. É avessa ao condomínio, que tolera como uma situação transitória; tem na posse um instrumento avançado de defesa (interditos) e nas ações petitórias (reivindicatória, negatória) o instrumento adequado de tutela; e desdobra-se em direitos reais limitados de gozo (que se tutelam por interditos e ações confessórias) e de garantia (créditos privilegiados)."
\end{abstract}

Em apertada síntese, podemos destacar alguns elementos que caracterizam esta forma de propriedade, em sua acepção privada, a fim de reconhecer em seus traços as similitudes existentes com o que denominaremos de propriedade moderna, fazendo referência a "Propriété Napoléonienne".

Caio Mário da Silva Pereira define a propriedade como o direito de usar, gozar e dispor da coisa, e reivindicá-la de quem injustamente a detenha, reportando-se ao conceito romano "Dominium est jus utendi fruendo et abutendi re sua quatenus juris ratio patitur" (O domínio é o direito de usar, fruir e dispor do que é seu, quanto o permite a razão do direito). ${ }^{3}$

\footnotetext{
2 PILATI, José Isaac. Revista Seqüência, n ${ }^{5}$ 9, dez. 2009, página 96.

${ }^{3}$ PEREIRA, Caio Mário da Silva. Instituições de Direito Civil. Direitos Reais, IV. 21. a ed. Rio de janeiro: Forense, 2013, p.75.
} 
Já Orlando Gomes propõe uma abordagem conceitual divida em três critérios: o sintético, o analítico e o descritivo. A conceptualização sintética pressupõe "a submissão da coisa, em todas as suas relações, a uma pessoa", a analítica, "o direito de usar, fruir e dispor de um bem, e de reavê-lo de quem injustamente o possua", e a descritiva como "o direito complexo, absoluto, perpétuo e exclusivo, pelo qual uma coisa fica submetida à vontade de uma pessoa, com as limitações da lei.",4

Através da análise conjunta destes três conceitos, tem-se uma noção do direito de propriedade. Contudo, alerta-nos o autor, é "através da análise de suas características que a propriedade se torna mais nítida”. Entre suas características, Gomes ressalta que a propriedade é um direito complexo, absoluto, perpétuo e exclusivo. A propriedade é um direito complexo, na medida em que reúne uma série de direitos a ela imanente, como as faculdades de usar, gozar, dispor e reivindicar a coisa que lhe serve de objeto. A propriedade é revestida de um caráter absoluto, característica essa que deve ser entendida sob duas óticas distintas: a faculdade do sujeito de disposição dos direitos inerentes a propriedade, oponíveis erga omnes, e o "aspecto real de poder sobre a coisa que se distingue das demais relações jurídicas". A primeira concepção coaduna com a ideia de que "cabe ao titular da propriedade decidir se deve usar a coisa, abandoná-la, aliená-la, destruí-la (...)”. A segunda, já relativizada no direito contemporâneo pela necessidade observância dos preceitos de ordem econômica e social, pela tutela do meio ambiente e do patrimônio histórico e artístico, diz respeito finalidade que será dada a propriedade. Seria "absoluta" pois, ainda que objeto de certas limitações, o poder jurídico de "dominação sobre a coisa fica ileso em sua substancialidade".

Por fim, a propriedade é dotada de perpetuidade, em regra, pois não

\footnotetext{
${ }^{4}$ GOMES, Orlando. Op.cit., p. 103.
} 
há uma duração limitada ao exercício dos direitos a ela imanentes. ${ }^{5}$

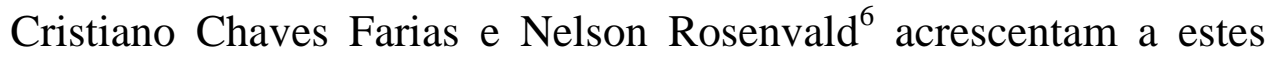
direitos, também citada por Orlando Gomes, a faculdade do proprietário de reivindicar. Trata-se aqui, em oposição ao domínio, que é o exercício direto do proprietário sobre sua propriedade, de um direito externo, direito este exercido frente a uma lesão ao direito subjetivo de propriedade, ou seja, quando há desrespeito ao dever de abstenção.

Na mesma linha, Caio Mário ${ }^{7}$ defende que o direito de propriedade está na substância da coisa, e que nesta substância estão inseridos direitos elementares, dentre eles o direito de reivindicar a posse de quem injustamente a detenha, sem que por isso tenha o proprietário seus direitos afetados. Ressalta porém, a relativização deste conceito frente a nova doutrina da função social da propriedade, a qual nos debruçaremos em momento oportuno.

Quanto à análise do objeto que envolve o conceito de propriedade, há divergência doutrinária quanto aos que defendem serem estes de duas naturezas; corpóreos e incorpóreos (abrangendo estes a propriedade de bens artísticos e literários, e demais bens imateriais).

Caio Mário define como objeto da propriedade tanto os bens corpóreos como os incorpóreos, tendo em vista que compreende ser a diferenciação como uma mera questão de terminologia, pois, citando Ruggiero e Maroi, "se a rigor a propriedade compreende apenas as coisas corpóreas, estende-se, entretanto o conceito dominial aos direitos ${ }^{8 \%}$. A prática cotidiana que familiarizou a utilização do conceito de propriedade abrangendo também os bens incorpóreos, sustenta, levou Serpa Lopes a qualificar de elástico o conceito de propriedade.

Ao delimitar o que se compreende como o objeto que envolve o

\footnotetext{
${ }^{5}$ GOMES, Orlando, Op. Cit., p.104.

${ }^{6}$ FARIAS, Cristiano Chaves e ROSENVALD, Nelson, Op. cit., p. 190.

7 PEREIRA, Caio Mário da Silva, Op. cit., p.80.

${ }^{8}$ PEREIRA, Caio Mário da Silva, Op. cit., p. 81.
} 
conceito de propriedade, ressalta Gomes que, além da natureza corpórea, deve este ser especificadamente determinado. Isto se dá devido ao fato de ser necessário poder individualizar os bens que constituem, por exemplo, um patrimônio.

Orlando Gomes acrescenta que a disciplina legal do objeto do direito de propriedade deve subordinar-se a três princípios: o da materialização, o da individualização e o da acessoriedade ${ }^{9}$.

Esta ultima categorização merece especial atenção, uma vez que deve ser entendida em consonância com a ideia de que o objeto em questão "deve ser especificadamente determinado". Isto pois, como salienta

Orlando Gomes: "O objeto do direito de propriedade deve ser o valor econômico materializado, individualmente determinado, com todos os acessórios da coisa". ${ }^{10}$

A propriedade comum privada é então compreendida como um bem corpóreo, especificamente determinado, caracterizado pela exclusividade, perpetuidade e cujo titular é dotado de um direito real absoluto, oponível, salvo limitações, erga omnes. Se nos atermos aos conceitos apresentados, dá-se a propriedade um aspecto meramente econômico e individualista, pois como bem define Orlando Gomes:

\footnotetext{
“Considerada na perspectiva dos poderes do titular, a propriedade é o mais amplo direito de utilização econômica das coisas, direta ou indiretamente. O proprietário tem a faculdade de servir-se da coisa, de lhe perceber os frutos e produtos, e lhe dar a destinação que lhe aprouver". 11
}

\section{B. Propriedade Comum Pública.}

\footnotetext{
${ }^{9}$ GOMES, Orlando, Op. Cit., p. 107.

${ }^{10}$ GOMES, Orlando, Op. Cit., p. 107.

${ }^{11}$ GOMES, Orlando, Op. Cit., p. 107.
} 
Dentro da categorização proposta por José Isaac Pilati, o conceito anteriormente apresentado de propriedade comum, em sua acepção privada, contrapõe-se tradicionalmente a propriedade pública, esta regida pelo direito administrativo. Diferenciam-se substancialmente quanto ao sua categorização jurídica e a sua titularidade. Neste mister, é necessário atentar para os sujeitos que possuem a capacidade para serem sujeitos do direito de propriedade. Sustenta Orlando Gomes ${ }^{12}$ que podem ser sujeitos do direito de propriedade tanto pessoas naturais quanto pessoas jurídicas, compreendidas as pessoas jurídicas de Direito Privado e de Direito Público. Por sua vez, a natureza do domínio exercido sobre a propriedade divide-se pela natureza daquele que efetivamente o exerce, dividindo-se em domínio público aquelas propriedades pertencentes ao Estado, e ao domínio privado as propriedades de natureza particular. Quanto ao conceito de Bens públicos, remetemo-nos as palavras de Celso Antônio Bandeira de Mello, que assim os define:

\footnotetext{
"Bens públicos são todos os bens que pertencem às pessoas jurídicas de Direito Público, isto é, União, Estados, Distrito Federal, Municípios, respectivas autarquias e fundações de Direito Público (...) bem como os que, embora não pertencentes a tais pessoas, estejam afetados à prestação de um serviço público. O conjunto de bens públicos forma o "domínio público", que inclui tanto bens imóveis como móveis."13
}

Os Bens públicos encontram definição no art. 98 do Código Civil que assim preceitua:

\footnotetext{
“Art. 98. São públicos os bens do domínio nacional pertencentes às pessoas jurídicas de direito público interno; todos os outros são particulares, seja qual for a pessoa a que pertencerem. “
}

De acordo com Celso Antônio Bandeira de Mello, as características que compõe o regime dos bens públicos são a Inalienabilidade, prevista no art. 100 do Código Civil de 2002, a Impenhorabilidade, que encontra previsão no art. 100 da Constituição Federal, e a Imprescritibilidade, que regula-se

\footnotetext{
12 GOMES, Orlando, Op. Cit., p. 105.

${ }^{13}$ BANDEIRA DE MELLO, Celso Antônio. Curso de Direito Administrativo $27^{\mathrm{a}}$ Edição, 2010. Editora Malheiros, São Paulo, p. 913
} 
pelo art. 102 do Código Civil, bem como pelos artigos $183, \S 3^{\circ}$ e art. 191 da CRFB. ${ }^{14}$

Neste ponto, discorre José Afonso da Silva:

"Qualquer bem pode ser de propriedade pública, mas há certas categorias que são por natureza destinadas à apropriação pública (vias de circulação, mar territorial, terrenos da marinha, terrenos marginais, praias, rios, lagos, águas de modo geral etc), porque são bens predispostos a atender o interesse público, não cabendo sua apropriação privada." ${ }^{15}$

Desta forma, os bens públicos subdividem-se em:

“Art. 99. São bens públicos:

I - os de uso comum do povo, tais como rios, mares, estradas, ruas e praças;

II - os de uso especial, tais como edifícios ou terrenos destinados a serviço ou estabelecimento da administração federal, estadual, territorial ou municipal, inclusive os de suas autarquias;

III- os dominicais, que constituem o patrimônio das pessoas jurídicas de direito público, como objeto de direito pessoal, ou real, de cada uma dessas entidades."

Os Bens Públicos de Uso Comum são aqueles que são "livres à utilização de todos", ou seja, cujo uso pode ser feito indistintamente por quaisquer sujeitos desde que de maneira "igualitária e harmoniosa com os demais, e de acordo com o destino do bem e condições que não lhe causem uma sobrecarga invulgar", ou seja, seu uso não necessita de uma manifestação administrativa aquiescente. ${ }^{16}$

Os Bens de uso Especial são aqueles onde estão "inseridos repartições públicas “, onde a atividade pública está à disposição dos administrados, compreendidas escolas, tribunais, museus. ${ }^{17}$

Já os bens Dominicais, ou dominiais, são aqueles "próprios do Estado como objeto de direito real, não aplicados nem ao uso comum e nem ao especial, tais os terrenos ou terras em geral, sobre os quais tem senhoria, à moda de qualquer proprietário, ou que, do mesmo modo, lhe assistam encontra de

14 BANDEIRA DE MELLO, Celso Antônio, Op. cit, p 915-916.

15 SILVA, José Afonso da. Curso de Direito Constitucional Positivo. $27^{\text {a }}$ edição, Editora Malheiros, São Paulo, 2006,.p. 275.

${ }^{16}$ BANDEIRA DE MELLO, Celso Antônio, Op. cit, p 925-926.

${ }^{17}$ BANDEIRA DE MELLO, Celso Antônio, Op. cit, p 914. 
direito pessoal.",18

Os bens dominicais pertencem a maior classe de bens públicos, com vasta abrangência, e que compõe os patrimônios da União, dos Estados e Municípios. Sob essa categorização encontram-se também abrangidas as terras devolutas. Celso Antônio Bandeira de Mello entende as terras devolutas como sendo:

“ as que, dada a origem pública da propriedade fundiária no Brasil, pertencem ao Estado - sem estarem aplicadas a qualquer uso público - porque nem foram trespassadas do Poder Público aos particulares, ou, se o foram, caíram em comisso, nem se integraram no domínio privado por algum título reconhecido como legítimo." 19

\section{O Binômio Publico X Privado na propriedade moderna.}

A propriedade dita "comum", sob a categorização proposta por Pilati, apresenta um paradigma a ser superado. Se nos ativermos aos aspectos que ressaltamos anteriormente, tal concepção simplifica e abstrai o conceito de propriedade, retirando-lhe o aspecto primeiro da relação, qual seja a noção de subsistência, muitas vezes de uma coletividade, e das relações construídas com base em factualidades e crenças religiosas, em experiências reais. A propriedade é reduzida a aspectos meramente econômicos e formais, e calcada em uma figura individualista, externada pelo conceito de dominium, e da complexidade de direitos a ele imanentes.

Tal reducionismo é sentido pelo autor, que sobre isto discorre, propondo que esta concepção de propriedade:

\footnotetext{
"Atua reduzindo o universo subjetivo aos dois interlocutores: indivíduo proprietário e Estado pessoa. No plano do objeto, restringe os bens jurídicos às duas categorias: públicos e privados. À base desses elementos, o direito subjetivo da dominialidade submete os objetos corpóreos à lógica proprietária, em substância, essência e erga omnes, com as limitações da lei; ou seja, outorgando ao Direito a função limitada de forma, a serviço da liberdade que nasce do ter, e que privilegia as relações
}

\footnotetext{
${ }^{18}$ BANDEIRA DE MELLO, Celso Antônio, Op. cit, p 914.

19 BANDEIRA DE MELLO, Celso Antônio. Curso de Direito Administrativo $27^{\text {a }}$ Edição, 2010. Editora Malheiros, São Paulo. p..464.
} 
econômicas. ${ }^{20}$

Para Pilati, a propriedade moderna é reduzida a uma gama de direitos, tutelados sob uma ótica autocrática. Estes direitos, transformados em lei, colocam a coletividade sob a égide do monopólio da jurisdição Estatal, e esta por sua vez garante ao "indivíduo proprietário" a plena disposição de seus bens, abominando desta maneira qualquer forma participativa no que diz respeito a propriedade. A propriedade estaria, portanto, sempre sujeita "ao binômio do estatismo e individualismo proprietário".O autor discorre neste sentido, ao afirmar que:

"Imperando hegemonicamente esse modelo da Propriedade Moderna, o Estado tende a desautorizar qualquer centro de poder que fuja desse padrão codificado; monopolizando a produção jurídica, procurou sempre reduzir as formas de propriedade privada a uma só, a individual." 21

Esse reducionismo pode ser compreendido como algo contranatural, na medida em que o conceito de propriedade não pode ser delimitado a uma única acepção. Neste ponto, atentamos para a lição de Caio Mário da Silva Pereira:

\footnotetext{
“ Não existe um conceito de propriedade. Muito erra o profissional que põe os olhos no direito positivo e supõe que os lineamentos legais do instituto constituem a cristalização dos princípios em termos permanentes, ou que o estágio atual da propriedade é derradeira, definitiva fase de seu desenvolvimento. Ao revés, envolve sempre, modifica-se ao sabor das injunções econômicas, políticas, sociais e religiosas. Nem se pode falar, a rigor, que a estrutura jurídica da propriedade, tal como se reflete em nosso Código é a determinação de sua realidade sociológica, pois que aos nossos olhos e sem que alguém possa impedilo, ela está passando por transformações tão substanciais quanto aquelas que caracterizaram a criação da propriedade individual, ou que inspiraram a sua concepção feudal". ${ }^{22}$
}

Se, como sustenta Caio Mário, a propriedade "modifica-se ao sabor

\footnotetext{
${ }^{20}$ PILATI, José Isaac. Op. cit., página 96.

${ }^{21}$ PILATI, José Isaac. Op. cit., página 9.

${ }^{22}$ PEREIRA, Caio Mário da Silva, Op. cit., p. 67.
} 
das injunções econômicas, políticas, sociais e religiosas", podemos afirmar que a propriedade moderna é antes de tudo fruto de uma construção, de um reflexo destas diferentes instâncias. Desta forma, é imperioso compreender em que contexto "econômico, político e social", ou seja, em que contexto histórico o conceito de propriedade moderna surgiu, a fim de compreendermos as razões de seu "absolutismo" que permeiam de certa forma as instituições jurídicas ocidentais até hoje, e a razão pela qual esta sustenta-se em um binômio propriedade Pública X Privada. Retroceder a esta origem é essencial para avançarmos na compreensão das questões que envolvem a propriedade, e compreender melhor em que bases se deram sua evolução. 


\section{Um retorno às origens históricas e ideológicas da propriedade moderna.}

A propriedade é um dos conceitos mais complexos existentes no direito. Se esta complexidade nos impede de extrair um conceito único, devido a multiplicidade de questões às quais a propriedade está relacionada, uma coisa, porém, pode ser afirmada; se a propriedade é cambiável e surge como reflexo das estruturas sociais, tanto quanto as modula, a propriedade é igualmente fruto de uma construção histórica.

Partimos da premissa de que na pós-modernidade não se pode mais falar em "uma propriedade" e sim em "propriedades", levando-se em conta a multiplicação e a complexificação dos institutos que regulam a matéria. Se não há um conceito único algo, porém, parece inato ao conceito de propriedade. Nos dizeres de Orlando Gomes:

“é inafastável o reconhecimento da historicidade do conceito do direito de propriedade, pois, sem embargo da projeção que emerge das fontes clássicas e se lança para o direito contemporâneo, o contexto histórico revela planos e vicissitudes irredutíveis a um conceito único". 23

A fim de corroborar com tal entendimento, apoiar-nos-emos em um primeiro momento no trabalho de Paolo Grossi, que defende que o "dominium" garante a continuidade entre as diversas formas de propriedade, sendo o fio condutor que liga o dominium clássico, os dominia dos Glosadores, e a propriedade dos Pandectistas. Partir de tal premissa nos dará as bases para uma melhor compreensão do contexto histórico em que se formou a concepção da propriedade moderna, podendo estabelecer com mais afinco quais influências ideológicas econômicas e políticas modularam de certa forma a dita "Propriété Napoléonienne".

\footnotetext{
${ }^{23}$ GOMES, Orlando. Op.cit. p.7.
} 


\section{A. A propriedade como "construção de mentalidades".}

A previsão do direito de usar, gozar e dispor da coisa, aspectos ressaltados na definição do conceito de propriedade, são os principais atributos do dominium, cuja oponibilidade e disposição, embora recentemente relativizados sob a nova ótica do código civil, permanecem como o substrato de um direito personalíssimo calcado na individualidade.

Dessa afirmação pode se extrair dois elementos caracterizadores da propriedade moderna: a de que esta concentra-se na figura do sujeito, e de que atende a uma finalidade pautada em interesses ideológicos e políticos, assumindo "a substância de uma ordem organizadora da vida quotidiana"24. A propriedade moderna torna-se então instrumento, e adquire novas formas de legitimação.

Se, como alertou Caio Mário, este conceito de propriedade não é finito, e vive ao "sabor das injunções econômicas, políticas, sociais e religiosas", como explicar seu absolutismo? Quais eventos levaram a construção deste conceito, tão enraizado na cultura ocidental?

Devemos atentar para os ensinamentos de Paolo Grossi, professor catedrático de História do Direito Medieval e Moderno na faculdade de Florença, Itália, que defende em seu ensaio "História da Propriedade" um outro tipo de abordagem: a de que a propriedade é, de fato, mentalidade.

Segundo Grossi, uma mera análise da "paisagem" histórica, ou de dados sobre a evolução agrária são insuscetíveis de captar a verdadeira essência da propriedade:

\footnotetext{
“ Se a mentalidade é aquele complexo de valores circulantes em uma área espacial e temporal capaz, pela sua vitalidade, de superar a diáspora de fatos e episódios espalhados e de construir o tecido conectivo escondido e constante, e deve portanto ser colhido como realidade unitiva.(...) nela (a propriedade), talvez mais do que qualquer outro instituto do direito, exalta-se e exaspera o que está dizendo agora do jurídico, porque ela, rompendo a trama superficial das formas, liga-se necessariamente, por um lado, a uma antropologia, a uma visão do homem no mundo, por outro, em graça de seu vínculo estreitíssimo com interesses vitais de indivíduos e de classes, uma ideologia. A
}

\footnotetext{
${ }^{24}$ GROSSI, Paolo. Op.cit. p. 65.
} 
propriedade é, por essas insuprimíveis raízes, mas do que qualquer outro instituto, mentalidade, aliás, mentalidade profunda." 25

Podemos então afirmar, que para além da construção histórica, o conceito de propriedade foi gradativamente se instaurando nas mentalidades dos sujeitos e na cultura jurídica ocidental. A propriedade moderna, como vimos, apresenta uma série de características e traços distintivos próprios, que foram fruto de um projeto jurídico. Representa, antes de tudo, uma mudança no paradigma da realidade: muda estruturalmente a sociedade, ao mudar substancialmente a relação do homem com a terra, e consequentemente a sua relação com os outros e com o mundo.

Explica-se: a "propriedade" na baixa idade média, é pautada principalmente no que GROSSI define como "relação pura". Havia em sua essência uma divisão substancial: uma linha divisória entre exercício e titularidade. Não havia um formalismo, um complexo sistema de normas que a regulasse, mas sim um "sistema de situações reais". ${ }^{26}$

A "propriedade" medieval é plural, complexa, não em direitos potestativos e exclusivos, mas em "mil exercícios efetivos" que se definem e se modulam na consciência comum daqueles que através da experiência, criam e recriam a propriedade. A "propriedade" é fruto de uma construção real, de uma consciência comum, e retira sua legitimidade da experiência.

Nos dizeres de GROSSI : "uso, exercício, gozo: situações que exprimem com vivacidade, com a sua carnalidade, a familiaridade do homem com as coisas, o seu mesclar e o seu viver com elas" ${ }^{27}$. Tem-se não uma forma definida, mas mil formas de "figuras que emergem da experiência", "mais instituídas que pensadas", constituindo-se assim não uma sociedade proprietária, mas uma sociedade possessória. Donde a dificuldade de se usar o termo "propriedade" medieval.

\footnotetext{
${ }^{25}$ GROSSI, Paolo. Op.cit. p. 31.

${ }^{26}$ GROSSI, Paolo. Op.cit. p.44-45.

${ }^{27}$ GROSSI, Paolo. Op.cit. p.46.
} 
$\mathrm{Na}$ alta idade média, frente ao complexo emaranhado de situações jurídicas que foram criadas, o Renascimento jurídico repensa estas relações reais através de uma figura do direito romano: o dominium utile. Figura importada, "instrumento interpretativo e inventivo romano", o dominium utile surge como "modelo de legitimidade de toda ordem jurídica real, e, talvez- funesta imobilização de toda história jurídica ocidental - mais simplesmente, de toda ordem jurídica". ${ }^{28}$

Carregando consigo as próprias contradições, na medida em que opõe a "soberania imperiosa do individuo" ao uso e gozo das coisas, o dominium utile aparece como uma "renovada noção de pertencimento: se do mundo torna ao auge uma leitura no prisma da propriedade, os fatos concernentes à utilitas podem e devem encarnar uma propriedade". ${ }^{29}$

O domínio útil foca sua atenção na coisa em si, constrói-se na própria utilitas, e demonstra sua incapacidade de enxergar a propriedade como uma construção real, factual. Dá-se assim "corpo" a propriedade medieval, tornando-a instrumento a partir do qual age o animus do sujeito, vinculando-a a concepção romanística da relação sujeito e terra. Tem-se assim uma relação de poder, exercida autonomamente e imediatamente pelo homem sobre a terra, dividindo então aqueles que possuem poder sobre toda a coisa, dominia, e aqueles que possuem apenas direitos relativos a propriedade, ius in re alinea, poderes estes que, por não afetarem a coisa em sua substancialidade não se confundem com o pertencimento, e portanto, não constituem dominia. Constrói-se assim, paulatinamente a dimensão proprietária, dando ao sujeito uma gama de poderes, direitos reais sobre a coisa: servidão, aquisição dos frutos por separação etc... Diz Grossi:

\footnotetext{
"As velhas propriedades estavam no real, escritas nele e nele lidas e transcritas com humildade; o novo encontrará no real somente uma manifestação externa, um campo de ação eficaz pelo que potencialmente já existe no interior do sujeito e que pede somente para exprimir-se e concretizar-se. A propriedade torna-se um capítulo da história da transformação humanística geral, certamente não o último, mas um dos pontos de
}

\footnotetext{
${ }^{28}$ GROSSI, Paolo. Op.cit. p. 48.

${ }^{29}$ GROSSI, Paolo. Op.cit. p. 51.
} 
compromisso da nova especulação. ${ }^{30}$

Alerta-nos Paolo Grossi, como já ressalvamos anteriormente, que a concepção de dominium medieval não pode ser confundida com a propriedade moderna. Representa antes, um ponto comum, um continuum como define o autor: "Os dominia constituem porém sempre uma propriedade, são sempre uma resposta a procura daquele momento mais intenso do pertencimento que, com as suas já assinaladas descontinuidades, é porém o fio condutor que liga o dominium clássico, os dominia dos Glosadores, a propriedade dos Pandectistas."

\section{B. Dominium sui: a interiorização da propriedade no âmbito do sujeito.}

Se não se pode falar de confusão entre a "propriedade" medieval e a propriedade moderna, reconhece-se que ambas possuem no dominium um substrato comum, que garante a continuidade de uma racionalidade, e ousamos, possuem ambas em suas raízes a mentalidade proprietária em diferentes níveis. Tentaremos expor, em apertada síntese, quais elementos substanciais levaram a diferenciação entre a propriedade alto medieval e a construção da mentalidade da propriedade moderna.

A propriedade medieval possuía uma fraqueza inerente a sua concepção; o fracionamento de direitos sobre um mesmo bem tende a desmembrá-lo, tornando assim sua unidade algo frágil. A concepção moderna de propriedade deve então buscar novas formas de legitimação que garantam a unidade da propriedade. Neste ponto, assistimos ao recrudescimento de uma faceta já presente na ideia do dominium utile, a do animus do sujeito sobre a coisa, de seu "poder" sobre a coisa como forma

\footnotetext{
${ }^{30}$ GROSSI, Paolo. Op.cit. p. 64.

${ }^{31}$ GROSSI, Paolo. Op.cit. p.55.
} 
de legitimação da propriedade:

\begin{abstract}
“ A propriedade, que renega as soluções medievais do pertencimento e que podemos convencionalmente qualificar como moderna, é desenhada a partir do observatório privilegiado de um sujeito presunçoso e dominador, é emanação das suas potencialidades, é instrumento da sua soberania sobre a criação: uma marca rigorosamente subjetiva a distingue, e no mundo dos fenômenos, na sua objetividade, é somente o terreno sobre o qual a soberania se exercita; não uma realidade condicionante com suas pretensões estruturais, mas passivamente condicionada". ${ }^{32}$
\end{abstract}

Cria-se uma relação tripartite entre três conceitos complexos, mas que relevam, em sua leitura conjunta, aspectos basilares da construção da nova mentalidade proprietária: sujeito, soberania e simplicidade.

A complexa "propriedade" medieval, construída através de situações reais e factuais, ou sua concepção mais tardia onde a propriedade decorria do objeto, de sua utilitas, e do emaranhado de direitos inerentes a res, é agora simplificada, e busca sua legitimidade no âmbito do próprio sujeito:"A simplicidade testemunha a escolha de tirar o dominium das variações do contingente para torná-lo absoluto no âmbito do sujeito, inserindo-o o mais possível no interior dele." $" 33$

Interiorizada no âmbito do sujeito, a propriedade adquire sua legitimidade e seu absolutismo, na medida em que torna-se extensão da vontade do sujeito, desprovida esta de qualquer liame com fatos externos.

Dá-se aqui um passo importante: do objeto definido, a propriedade adquire uma abstração, torna-se subjetiva: “a propriedade como dimensão das coisas tornou-se dimensão do agente; ao invés de identificar-se grosseiramente no bem objeto, procura no interior do sujeito a sua identificação primeira." 34

Esta transformação marca substancialmente a evolução do conceito de propriedade: “ não nutrimos dúvidas de que a simplicidade e abstração, na sua interdependência e consequencialidade, constituem o "segredo" de uma propriedade inserida no "moderno" e dele especular; a sua

\footnotetext{
32 GROSSI, Paolo. Op.cit. p.67.

${ }^{33}$ GROSSI, Paolo. Op.cit. p.68.

${ }^{34}$ GROSSI, Paolo. Op.cit. p.68.
} 
"modernidade", entendendo como tal a expressão a sua acentuada historicidade em um definido universo cultural e portanto inconfundível caráter, está sobretudo nessas duas qualidades". 35

Os conceitos acima apresentados apresentam a evolução de um pensamento que, como vimos, evolui histórica e conceitualmente: a abstração e a simplificação da propriedade moderna, consistentes na interiorização do dominium no âmbito do sujeito vão constituir "a pedra angular da cultura filosófico político-jurídica da idade moderna.”,36

O projeto jurídico revela finalmente sua verdadeira faceta:

\footnotetext{
“ Aqui a propriedade se torna a criatura jurídica congenial ao homo oeconomicus de uma sociedade capitalista evoluída: um instrumento ágil, conciso, funcionalíssimo, caracterizado por simplicidade e abstração (...). É nesta transcrição ao sujeito que ela reclama a sua unidade e a sua indivisibilidade, una e indivisível como ele, porque como ele é síntese de virtude, capacidade e poderes. Uma transcrição tão aderente a ponto de parecer quase uma fusão: a propriedade é somente o sujeito em ação, o sujeito à conquista do mundo." ${ }^{37}$
}

Se a partir de agora podemos afirmar que a propriedade é sobretudo "mentalidade", é fundamental determinarmos em que momento histórico esta mentalidade foi inserida em nossa cultura.

\section{O contexto histórico da propriedade moderna.}

O iluminismo e o jusnaturalismo, correntes de pensamento ligados à Revolução Francesa, surgem como o marco de influência do direito clássico de propriedade, e representam igualmente um momento de transição no pensamento ocidental, em diversos campos do $\operatorname{saber}^{38}$. O homem, antes preso as amarras da religião e da estratificada ordem social na qual estava inserido, agora surge como o eixo do pensamento moderno, e pauta-se em

\footnotetext{
${ }^{35}$ GROSSI, Paolo. Op.cit. p.72.

${ }^{36}$ GROSSI, Paolo. Op.cit. p.69.

${ }^{37}$ GROSSI, Paolo. Op.cit. p. 81-82.

${ }^{38}$ FARIAS, Cristiano Chaves e ROSENVALD, Nelson, Op. cit., p. 165.
} 
valores edificantes que marcam profundamente a concepção de propriedade: a racionalidade e a liberdade.

Esta liberdade, paradoxalmente garantida pelo Estado e por este inviolável, representa a conquista do homem moderno pelo reconhecimento de seus direitos, agora vistos como naturais, e esculpidos em um documento histórico de suma importância, a Declaração Universal dos Direitos do Homem e do Cidadão, de 1789, que assim determina:

\footnotetext{
“Art. 2. ${ }^{\circ}$ A finalidade de toda associação política é a conservação dos direitos naturais e imprescritíveis do homem. Esses direitos são a liberdade, a propriedade, a segurança e a resistência à opressão. “
}

Buscava-se, através da consolidação da $1^{\mathrm{a}}$ geração de direitos fundamentais, o estabelecimento de um estado de igualdade formal no qual exigia-se um dever de abstenção por parte do Estado. Nos dizeres de Cristiano Chaves de Farias e de Nelson Rosenvald:

\begin{abstract}
“ Defere-se ao homem razão e liberdade, sendo concedida uma sociedade composta por indivíduos isolados, portadores de direitos subjetivos invioláveis pelo Estado. Todos poderiam perseguir seus interesses e realizar seus ideais em um espaço de liberdade e igualdade formal, na qual os sujeitos abstratos não mais seriam qualificados por privilégios ou títulos nobiliárquicos, a par de suas diferenças sócias. Valoriza-se a autonomia privada, pois o acesso à terra independe da coerção de um senhor, ligando-se agora à vontade individual. A propriedade será alçada segundo a capacidade e o esforço de cada um (...)",39
\end{abstract}

Os ideais da revolução francesa tinham assim, por condão, democratizar a propriedade e garantir o seu acesso a todos, na medida de seus merecimentos, libertando assim o sujeito da velha ordem feudal. O "indivíduo proprietário" adquire um papel central na nova ordem econômica instaurada, tendo em vista que agora sujeito de direitos e senhor de suas capacidades, consegue este vender sua força de trabalho e atingir seus objetivos através de seu próprio esforço. Aqui atentamos para um trecho da obra de Hardt e Negri, cuja reflexão merece destaque:

\footnotetext{
${ }^{39}$ FARIAS, Cristiano Chaves e ROSENVALD, Nelson, Op. cit., p. 165.
} 


\begin{abstract}
"The concept of the individual is defined by not being but having; rather than to a "deep" metaphysical and transcendental unity, in other words, it refers to a "superficial" entity endowed with property or possessions, defined increasingly today in "patrimonial" terms as shareholder. In

effect, through the concept of the individual, the transcendent figure of the legitimation of property is integrated into the transcendental formalism of legality." 40
\end{abstract}

Se a igualdade formal instaurada pelo pensamento moderno garante a todos uma igualdade de direitos, a propriedade surge como um desejo; para além da obtenção dos meios necessários a sua subsistência, a propriedade surge como um símbolo de segurança, de liberdade.

\begin{abstract}
“A Revolução Francesa pretendeu democratizar a propriedade, aboliu privilégios, cancelou direito perpétuos. Desprezando a coisa móvel (vilis mobilium possessio), concentrou sua atenção na propriedade imobiliária, e o Código por ela gerado - Code Napoléon - que serviria de modelo a todo um movimento codificador no século XX, tamanho prestígio deu ao instituto, que com razão recebeu o apelido de "código da propriedade", fazendo ressaltar acima de tudo o prestígio do imóvel, fonte de riqueza e símbolo de estabilidade. Daí ter se originado em substituição à aristocracia de linhagem uma concepção nova de aristocracia econômica, que penetrou no século XX.",41
\end{abstract}

O Estado do período Iluminista aparece como o garantidor da propriedade. Sua proteção configura, nas palavras de Farias e Rosenvald, através do Código Civil Francês, um sistema de tutela da esfera patrimonial dos sujeitos, sendo este o espaço de liberdade e privacidade das pessoas, o qual não poderia sofrer intervenções do Poder Judiciário que limitassem a fruição e disposição por parte do proprietário. Tal absolutismo se vê configurado na art. 544 do Code Civil:

\footnotetext{
“Art. 544 La propriété est le droit de jouir et disposer des choses de la manière la plus absolue, pourvu qu'on n'en fasse pas un usage prohibé par les lois ou par les règlements." 42
}

\footnotetext{
40 HARDT, Michael; NEGRI, Antonio. “Commonwealth”, The Belknap Press of Harvard University Press, Cambridge, Massachusetts, 2009. p.7.

${ }^{41}$ PEREIRA, Caio Mário da Silva, Op. cit., p. 69.

${ }^{42} \mathrm{http} / / / \mathrm{www}$. legifrance.gouv.fr/
} 
Sobre este artigo, discorrem Michael Hardt e Antonio Negri:

"Moreover, when the right to property becomes once again central within the constellation of new rights afirmed by the bourgeois revolutions, it no longer stands simply as a real right but becomes the paradigm for all the fundamental rights. Article 544 of the 1804 Code Civil, for example, gives a definition of property that characterizes notions still common today (...) In the dominant line of European political thought from Locke to Hegel, the absolute rights of people to appropriate things becomes the basis and substantive end of the legally defined free individual." "43

Tal concepção de propriedade encontra suas feições no pensamento Iluminista, que elabora a teoria da criação do Estado a partir de um estado de natureza, inaugurando a ideia de contratualismo, que encontra fruto nas obras de três grandes nomes do pensamento moderno: Thomas Hobbes, John Locke e Jean Jacques Rousseau.

Rousseau parte do princípio de que no estado de natureza, o homem é naturalmente bom, mas a sociedade é quem o corrompe e o força a agir de maneira egoísta e individualista. Surgem em seu pensamento noções importantes como o "Interesse Geral", via adotada para se garantir, através do Estado e da ação dos cidadãos a "soberania do povo", dando essência a um pensamento democrático como sendo a via para o afastamento do estado de natureza.

Distancia-se portanto da noção de Thomas Hobbes, na medida em que este propõe a ideia de um estado de natureza no qual prevalece a lei do mais forte. Não haveria liberdade, na medida em que os homens viveriam em um contínuo estado de conflito. Seria necessário a construção de um Estado detentor do monopólio da força, para que fossem preservadas as garantias individuais, surgindo assim a ideia de contratualismo, onde todos abdicariam de uma parcela de suas liberdades para a garantia da segurança e da paz social. Neste contexto, somente com o advento da figura do Estado seria possível o estabelecimento da propriedade.

\footnotetext{
${ }^{43}$ HARDT, Michael; NEGRI, Antonio. Op.cit. p.13.
} 
Em contra partida, John Locke vê a propriedade não como um produto criado em decorrência da instauração de um Estado, mas como um direito natural. A figura do Estado surgiria para, através da noção de contrato social, garantir o estado de natureza e a salvaguarda do direito de propriedade, regulando-o através de normas e visando uma diminuição dos conflitos. A propriedade surge como um dos cernes de seu pensamento, pois atrelada a ela está a ideia de liberdade, e cujo acesso, como vimos, está intimamente ligado ao trabalho e ao merecimento do sujeito. Assim discorre José Pilati:

\begin{abstract}
"Locke justifica a apropriação com fundamento no trabalho, porém não para açambarcar a terra e sim para usufruirmos. Assim é de início, arremata: Direito e conveniência andando juntos, sendo inútil, bem como desonesto, tomar demasiado, ou mais do que o necessário. O dinheiro também se justificaria nessa linha: como meio de tornar durável (com a troca) o perecível, pois o desperdício é igualmente condenável. O liberalismo de Locke é preciso não só nesse aspecto, do mérito e dos limites da propriedade; ele baseia a relação de poder não no Estado como Hobbes; mas num estado de natureza anterior, que é de plena liberdade. Liberdade de indivíduos proprietários(...)"44
\end{abstract}

\title{
Frente a esta nova dogmática filosófica, discorre Paolo Grossi:
}

\begin{abstract}
“ Essa construção jurídica sem ambiguidades, descendente razoavelmente em todos os seus aspectos das premissas programáticas de índole ético-política (...) com essa grande operação doutrinal, a sociedade burguesa pode conclamar que tem também no plano jurídico uma propriedade autenticamente burguesa (...). Como a afirmação de uma liberdade e de uma igualdade formais tinham sido os instrumentos mais idôneos para garantir ao homo oeconomicus a desigualdade de fato das fortunas, assim essa propriedade "espiritualizada" teria se concretizado, por graça das suas ilimitadas possibilidades transformistas, na pedra filosofal da civilização capitalista: a mais pobre, a mais desencarnada das construções jurídicas ter-se-ia demonstrado um meio eficientíssimo para transformar tudo em ouro, instrumento pontual para todo tipo de mercantilização."
\end{abstract}

44 PILATI, José. Conceito e Classificação da propriedade na pós-modernidade: a era das propriedades especiais. Trabalho defendido no II Encontro Temático do Projeto Casadinho UFC/UFSC, ampliado e transformado em artigo. In Revista Seqüência, no 59, p. 89-119, dez. 2009. p. 6.

${ }^{45}$ GROSSI, Paolo. História da Propriedade e outros ensaios. Editora Renovar. Rio de Janeiro,

2006, p. 83. 
Neste ponto, concedemos especial atenção aos estudos de Valcir Gassen $^{46}$ que, através de seus trabalhos, traça uma correlação entre as formas de propriedade e as fases da divisão do trabalho, utilizando-se das obras de Karl Marx e de Friedrich Engels, e pautando-se no conceito do materialismo histórico. Afirma o autor que, "com a divisão social do trabalho tem-se a propriedade privada, o Estado, a alienação da atividade social", e fazendo referência a obra dos mencionados autores, em " $A$ ideologia alemã", sustenta que a propriedade privada é o produto da atividade desenvolvida pelos homens, sendo portanto, a propriedade privada e a divisão do trabalho expressões idênticas. ${ }^{47}$

Sustenta GASSEN ${ }^{48}$, que há uma correlação entres os instrumentos de produção e as formas de propriedade. Utilizando-se da divisão estabelecida por Marx e Engels, atemo-nos aos instrumentos de produção criados pela civilização, quais sejam as máquinas e os próprios homens. Neste método de produção, discorre o autor no sentido de que os indivíduos encontram-se subordinados ao produto do trabalho, em que a propriedade da terra surge como domínio do trabalho, e o domínio que o proprietário exerce transformasse em dinheiro.

Acrescenta que, o pequeno proprietário fundiário, mesmo sendo proprietário, está amarrado aos modos de produção capitalista. Na medida em que este não possuí dinheiro para investir em sua produção, torna-se este detentor apenas de sua própria força de trabalho, equiparando-se ao proletariado urbano. Neste sentido, explica o autor que "na agricultura, em todos os tempos, para Marx e Engels, a propriedade é consequência necessária dos instrumentos de produção de uma determinada época". ${ }^{4}$

O comércio possui, segundo o autor, um papel fundamental na divisão entre a produção e o intercâmbio, constituindo um fator relevante na formação da

\footnotetext{
${ }^{46}$ GASSEN, Valcir. Fundamentos da História do Direito, Coordenador Antônio Carlos Wolkmer, Editora Del Rey, Belo Horizonte 2009, $4^{a}$ edição.

${ }^{47}$ GASSEN, Valcir. Op. cit,. p. 163.

${ }^{48}$ GASSEN, Valcir. Op. cit,. p. 164.

${ }^{49}$ GASSEN, Valcir. Op. cit,. p. 165.
} 
propriedade moderna. Exemplo citado por Marx e Engels, o comércio de materiais têxteis permitiu um aumento das relações de comércio e um acumulo de capital por parte das corporações, gerando uma concorrência e dando origem à manufatura, mobilizando-se um grande grupo trabalhadores do campo, ou como cita, "uma massa de capital natural"50.

A expansão do comércio e das produções manufatureiras intensificase com a descoberta do Novo Mundo, iniciando-se a fase de acumulação primitiva de capital que mais tarde possibilitará a instauração dos modos de produção capitalista. A Revolução Industrial, período marcante desta fase histórica, marca a transição do período manufatureiro ao período do maquinismo, mas representa igualmente, e aqui destacamos, "o fim da supremacia da propriedade fundiária, visto que esta forma de propriedade, assentada em economias de base predominantemente agrícola, reinava quase que exclusiva em relação às outras formas de propriedade até então". 51 A Grande Industria, originada pelos períodos de navegação que se sucederam nos séculos XVII e XVIII, nos dizeres de Marx e Engels:

\footnotetext{
"universalizou a concorrência, estabeleceu os meios de comunicação e o mercado mundial moderno, submeteu a si o comércio, transformou todo o capital em capital industrial, e criou assim rápida circulação e concentração de capitais (...) completou a vitória da cidade comercial sobre o campo". 52
}

A propriedade moderna surge como o fruto não apenas de uma corrente filosófica, e dos pensamentos Iluministas oriundos da Revolução Francesa, mas também como o produto de um materialismo histórico, e da estreita relação existente entre as formas de divisão do trabalho e as formas de propriedade dela decorrentes. Neste ponto, atentamos uma última vez aos ensinamentos de GASSEN, que em brilhante síntese resume esta transição no pensamento do direito moderno e da construção do conceito de propriedade moderna:

\footnotetext{
${ }^{50}$ GASSEN, Valcir. Op. cit,. p. 168.

${ }^{51}$ GASSEN, Valcir. Op. cit,. p. 168.

52 GASSEN, Valcir. Op. cit, Apud, MARX, Karl; ENGELS, Friedrich. A ideologia Alemã. São Paulo: Moraes, p77-78
} 


\begin{abstract}
"Nesse contexto, com o advento da modernidade, é retomado o direito romano que tratava da propriedade. A incorporação do direito romano pela burguesia emergente não se deu somente pelo fato de que este direito tinha uma "logicidade interna"; ou que era o direito mais bem elaborado de que se tinha conhecimento, mas principalmente porque as formulações teóricas que ele continha atendiam às necessidades de legitimação da acumulação denotadas no modo de produção capitalista que aí surgia". 53
\end{abstract}

\title{
D. O "État-providence" e a função social da propriedade.
}

A propriedade surge como o instituto chave das novas aspirações burguesas, e o Estado Republicano, detentor firme de um monopólio autocrático jurisdicional, garante através da edição de leis o absolutismo da propriedade. Resta assim demonstrado a íntima interligação entre o capital e as leis no que se refere a proteção da propriedade privada, como haviam preconizado Hardt e Negri. Os autores defendem que, em ambas as três revoluções burguesas- a Americana, a Francesa e a Inglesa- constrói-se através das previsões constitucionalmente positivadas o que denominam de uma "Republica da Propriedade". Neste ponto específico, discorrem os autores:

\begin{abstract}
"But one specific definition of modern republicanism eventually won out over the others: a republicanism based on the rule of property and the inviolability of the rights of private property, which excludes or subordinates those without property. The propertyless are merely, according to Abbé Sieyès, "an immense crowd of biped instruments, possessing only their miserably paid hands and an absorbed soul." 54
\end{abstract}

Sobre este cenário, também discorrem Rosenvald e Farias:

“ Os valores da liberdade individual e da igualdade formal não poderiam prosperar em cenários de extenso desequilíbrio econômico. A liberdade de uns importa na opressão de uma massa de pessoas, privadas de acesso a bens mínimos e excluídas até de sua especial dignidade. (...) Ao contrário do que preconizavam os arautos da racionalismo, a inteligência humana produziu a liberdade, mas não nos permitiu enxergar o outro. Tornamo-nos cegos e surdos diante dos que nos cercam." ${ }^{, 55}$

\footnotetext{
${ }^{53}$ GASSEN, Valcir. Op. cit,. p. 174.

54 HARDT, Michael; NEGRI, Antonio. Op.cit p.9.

${ }^{55}$ FARIAS, Cristiano Chaves e ROSENVALD, Nelson, Op. cit., p.196.
} 
$\mathrm{O}$ "enorme contingente" excluído da lógica capitalista, aqueles que estavam a margem do processo econômico e social que estava se instalando, darão início a uma reviravolta na concepção de propriedade até então admitida. As desigualdades resultantes deste processo representarão um estopim para a luta por uma justiça social e uma justa distribuição das riquezas. Aqui transcrevemos uma célebre frase proferida por Pierre-Joseph Proudhon : "La propriété c'est du vol!".

O Estado, antes garantidor da livre fruição da propriedade por parte dos indivíduos, passará a ser o garantidor de uma justiça social. A Republica, erigida sob a tríade da liberdade, igualdade e fraternidade, passará não mais a ser uma figura garantidora, mas a agir na consecução dos princípios que a nortearam. A propriedade passa de um simples objeto a ser tutelado, a um instrumento cuja finalidade é a garantia de um bem estar que se dirige à coletividade.

As lutas trabalhistas empreendidas no séc. XIX frente às lastimáveis condições de trabalho impostas pela Revolução Industrial podem ser simbolicamente utilizadas como um exemplo da transição do papel do direito na tutela dos interesses da coletividade. A luta pela redução na jornada de trabalho, pela abolição do trabalho infantil, por uma política assistencialista em caso de acidentes de trabalho pautam as diferentes reivindicações das lutas empreendidas pela classe operária. Destaca-se o importantíssimo papel das organizações sindicais na luta do operariado, e a corrente ideológica do comunismo, notadamente na Revolução Russa, que orientaram suas lutas por uma igualdade social.

A Constituição de Weimar promulgada em 1919 é um dos três documentos basilares que representam este período de lutas e conquistas, juntamente com a constituição Mexicana de 1917, oriunda das lutas do campesinato Zapatista, e a Declaração dos Direitos do Povo Trabalhador e Explorado, documento resultante das lutas revolucionárias na Rússia, datado de 1918. A Constituição de Weimar representa um marco no avanço 
do reconhecimento destes direitos, afirmando em seu art. $4 \S 2^{\circ}$ que "a propriedade obriga" ${ }^{, 56}$, fundando assim a noção de função social da propriedade. O Estado passa a intervir na esfera patrimonial privada, impondo ao proprietário obrigações positivas frente à comunidade. Esta noção de intervencionismo já estava presente no pensamento de Leon Duguit em sua obra "Fundamentos do Direito", onde este defendia que a propriedade deveria atender a sua função social, superando-se assim o absolutismo da velha propriedade burguesa.

Destas lutas surgem os direitos sociais, que marcam a passagem de um Estado Liberal para um Estado Social, e influenciam as constituições vindouras que passam a impor "limites a atividade econômica e a função social dos direitos subjetivos" garantindo assim "uma nova ordem pública constitucional e devem ser encarados como meios de ampla tutela dos direitos essenciais do ser humano". Muda-se a racionalidade do ordenamento jurídico, que apenas “concederá merecimento à persecução de um interesse individual se este for compatível com os anseios sociais que com ele se relacionam"57. Cientes da transposição do Estado Social para o Welfare State, cujo marco encontra-se no Plano Marshal, e de que esta forma de estado apresenta-se em verdade como uma forma de resposta as correntes socialistas oriundas do Leste Europeu no séc. XX focamos aqui em guisa de uma construção mais concisa, no marco jurídico estabelecido com as conquistas sociais, e as influências de sua força normativa nas legislações e nas constituições vindouras.

Muito embora a Constituição Federal de 1937 já tivesse uma previsão quanto a limitações da propriedade privada, foi a Constituição de 1946 quem realmente estabeleceu que a propriedade deveria atender a sua função social e agir no sentido de garantir o bem-estar social ${ }^{58}$, marcando

\footnotetext{
${ }^{56}$ FARIAS, Cristiano Chaves e ROSENVALD, Nelson, Op. cit., p.203.

${ }^{57}$ FARIAS, Cristiano Chaves e ROSENVALD, Nelson, Op. cit., p. 198.

58 “Art. 141, § 16 - É garantido o direito de propriedade, salvo o caso de desapropriação por necessidade ou utilidade pública, ou por interesse social, mediante prévia e justa indenização em dinheiro. Em caso de perigo iminente, como guerra ou comoção intestina, as autoridades
} 
assim a transição no direito constitucional Brasileiro, sob a influência direta das reformas constitucionais Europeias, dentre elas a já citada Constituição de Weimar. Parafraseando ROSENVALD E FARIAS, quanto a propriedade, a "visão romanística, egoística e individualizada sucumbiu em face da evolução da humanidade",59.

Atualmente, nosso ordenamento pátrio garante através de diversos dispositivos a finalidade da propriedade em vista de sua função social, seguindo a ratio da evolução constitucional desde 1946. O artigo $5^{\circ}$ da Constituição Federal de 1988 estipula em seu inciso XXII que "é garantido o direito de propriedade" e em seu inciso XXIII que "a propriedade atenderá a sua função social". No mesmo sentido, o art. 170 da CRFB em seus incisos II e III, garante sob o capítulo dedicado a Ordem Econômica e Financeira, de um lado a propriedade privada, e de outro, a necessária observância quanto à sua função social.

A mudança de paradigma, através da modificação da função do papel do Estado com relação a propriedade, conquistadas através das lutas empreendidas durante os séculos XIX e XX, nos permite afirmar que, embora ainda persistam certos aspectos da propriedade comum privada, esta tende a cada vez mais limitada e a transforma-se para atender aos anseios do povo. Esta mudança de paradigma teve efeitos concretos na classificação "das propriedades" ditas "pós-modernas", e aqui nos concentramos na segunda categorização proposta por José Pilati, a das propriedades ditas "especiais".

competentes poderão usar da propriedade particular, se assim o exigir o bem público, ficando, todavia, assegurado o direito a indenização ulterior."

“Art 147 - O uso da propriedade será condicionado ao bem-estar social. A lei poderá, com observância do disposto no art. 141, § 16, promover a justa distribuição da propriedade, com igual oportunidade para todos. " Disponível em: http://www.planalto.gov.br/ccivil_03/constituicao/constitui\%C3\%A7ao46.htm

59 FARIAS, Cristiano Chaves e ROSENVALD, Nelson, Op. cit., p.204. 


\section{As “Propriedades Especiais".}

\section{A. Conceito}

Trata-se aqui de uma nova categorização "das propriedades" que na pós-modernidade surgem, seguindo a ratio da função social anteriormente explicitada, numa nova categorização proposta por José Pilati. Esta nova categoria possui sua importância, pois segundo o autor, contrapõem de um lado "o voluntarismo individualista" e de outro "a dependência de procedimentos e de decisões compartilhadas", passa-se em teoria do "indivíduo" para o "coletivo".

Garante o autor que há uma "reconstituição de todo o paradigma da propriedade", levando-se em conta a pluralidade de formas e de instrumentos de participação previstos em lei. As Propriedades Especiais possuem um perfil que se caracteriza por 3 elementos: (i) tem origem constitucional; (ii) são reguladas por meio de leis especiais e (iii) dependem de um ente estatal de apoio e de mediação (cita como exemplos: FUNAI, INCRA e demais agências reguladoras). A própria propriedade ganha classificações diversas sob esta nova categorização, passando a existir o "bem coletivo", e as próprias classificações jurídicas sofrem alterações: fala-se de "entidade" ao invés de "bem"; de "investidura" ao invés de "aquisição"; e substitui-se o "domínio" pela "titularidade". Segundo o autor, as implicações destas mudanças são profundas na medida em que impõem "harmonização e compatibilidade com interesses de dimensões não imaginadas pela propriedade moderna" ${ }^{\prime 60}$.

Há de fato uma translação entre desequilíbrios de ordem patrimonial, que antes contrapunham interesses individuais, mediados estes pelo aparelho Estatal, e que agora tratam de um outro sentido mais "amplo": trata-se de um patrimônio que pode pertencer a uma coletividade, a um povo, a

\footnotetext{
${ }^{60}$ PILATI, José Isaac. Op.cit. p.10.
} 
humanidade inteira ou ainda as gerações vindouras ${ }^{61}$, cujo exemplo maior pode ser dado com o surgimento das leis ambientais e a busca por um equilíbrio ecológico.

\section{B. Classificações.}

Segundo Pilati, as Propriedades Especiais por sua vez podem ser classificadas em propriedades especiais particulares, em propriedades público privadas e em propriedades especiais coletivas. As propriedades especiais coletivas por sua vez, subdividem-se em três categorias, podendo ser patrimoniais, étnicas ou extrapatrimoniais.

\section{1) Propriedades Especiais Particulares.}

Esta categoria de Propriedade Especial diz respeito às propriedades urbanas e rurais que embora tratarem-se de propriedades particulares, estão estas sujeitas a observância da função social da propriedade prevista em diversos instrumentos normativos, como veremos à seguir.

A propriedade urbana, nos dizeres de Pilati, é aquela que se classifica como sendo destinada à moradia, ao comércio ou à indústria. Por características, tem por objeto bens corpóreos (bens imóveis), podendo quanto ao regime jurídico ser atribuído a título singular ou sob condomínio. Seus modos de aquisição e suas limitações são regidos pelo Código Civil, limitações estas que igualmente encontram-se dispostas em instrumentos administrativos e outros documentos legais.

A propriedade urbana, como fora afirmado acima, deve cumprir sua função social como dispõe o art.182 $\$ 2^{\circ}$ da CRFB. Os principais diretrizes da propriedade urbana estão previstas nas Leis de parcelamento do solo urbano $^{62}$ e das incorporações ${ }^{63}$, bem como na Lei 10.257 de 2001 , nomeada

\footnotetext{
61 PILATI, José Isaac. Op.cit. p.11.
}

62 Lei $n^{\circ} 6766$ de 1979. 
de Estatuto da Cidade, que prevê instrumentos participativos e democráticos. De fato, o Plano Diretor, que é instituído por meio de lei Municipal, garante instrumentos de participação como audiências públicas, plebiscitos e referendos que permitem a comunidade municipal participar ativamente das tomadas de decisões que influam sobre o "uso e gozo do solo na sua função social e também particular" (13). Há um distanciamento da concepção autocrática das decisões pautadas exclusivamente em instrumentos legais, e passa-se a garantir uma tomada de decisão mais plural e conciliatória na medida em que se tomam em conta os interesses da coletividade.

A propriedade rural por sua vez distancia-se da da propriedade urbana quanto ao seu regime jurídico e a sua função social. Pilati define a propriedade rural como aquela descrita no art. $4^{\circ}$ da Lei 8629 de 1993, sendo "rural o prédio rústico de área contínua, qualquer que seja a sua localização, que se destine ou possa se destinar à exploração agrícola, pecuária, extrativo vegetal, florestal ou agroindustrial. Leva ainda em conta a definição dada pelo Código Tributário Nacional, que define a propriedade rural como sendo o "imóvel que se situa fora do perímetro urbano, tem cadastro rural e recolhe imposto territorial rural",64

Contrariamente a propriedade urbana, outros são os critérios para que esta cumpra com sua função social, devendo atentar ao que estabelece a Constituição Federal em seu art. 186. A propriedade rural deve ter um aproveitamento racional e adequado de sua extensão, deve respeitar o meio ambiente e as leis que dispõe sobre as condições dos trabalhadores, devendo sempre visar seu bem estar, medidas estas cujas diretrizes estão previstas em diversos dispositivos legais ${ }^{65}$.

63 Lei n 4591 de 1964

64 Lei 5172 de 1966 , art. 29 e art. 32 parágrafos $1^{\circ}$ e $2^{\circ}$.

65 As diretrizes que tratam da unção social da propriedades urbana constam principalmente no Estatuto da Terra (Lei n${ }^{\circ} 4504$ de1964), na lei n 8629 de 1993, na lei 9393 de 1996 que dispõe sobre o Imposto Territorial Rural e as Leis 8171 e 8174 de 1991 que dispõe sobre a política agrícola. 
O plano diretor também aparece aqui como o instrumento de participação coletiva, ao lado da União Federal e do Parlamento que estabelecem as diretrizes gerais da propriedade rural e da reforma agrária, e de órgãos como o INCRA- Instituto Nacional de Colonização e Reforma Agrária que visa a execução das decisões adotadas pelos órgãos supramencionados.

José Pilati afirma que frente a estas mudanças, a questão agrária passa por um novo horizonte. Cita como exemplo a RPPN- Reserva particular do Patrimônio Natural ${ }^{66}$, modelo em que o proprietário opta, com o objetivo da preservação ambiental, abrir mão de certas prerrogativas que lhe são inerentes a fim de conceder a sua propriedade uma função social ou coletiva, dando-lhes ou não uma destinação econômica (como a exploração de recursos naturais, ou através da visitação de turistas). Segundo o autor, as redefinições trazidas pela Constituição de 1988 no que tange as propriedades rural e urbana representariam uma quebra do paradigma do individualismo jurídico e do voluntarismo Estatal, aderindo a estas propriedades uma funcionalização em prol da sustentabilidade e da solidariedade social, rompendo assim com a dicotomia publico/privada acrescentando-se uma dimensão coletiva a tomada de decisões. ${ }^{67}$

\section{2) Propriedade Especial público-privada.}

A propriedade Especial público-privada difere-se em essência da propriedade Pública comum, vez que são outros seus objetos. $\mathrm{O}$ objeto deste tipo de propriedade são os bens nacionais, explorados por empresas estatais ou privadas "mediante concessão da União, no interesse nacional, por brasileiros ou empresa constituída sob as leis brasileiras e que tenha sede e administração no país, na forma da lei”, como estabelece o art. 176 
$\S 1^{\circ}$ da $\mathrm{CRFB}^{68}$. São abrangidos como objetos todos os recursos minerais e potencializadores de energia hidráulica ( como o petróleo, o gás natural, hidrocarburetos fluidos etc..). A exploração destes potenciais no plano infraconstitucional se dá por diversos dispositivos e legislações específicas de cada setor ${ }^{69}$.

Afirma José Pilati que este modelo de propriedade difere-se da empresa privada comum, muito embora haja a previsão no Código Civil quanto a intermediação destas riquezas pela União, podendo inclusive ser objeto de hipoteca $^{70}$, na medida em que esta encontra-se sob os desígnios constitucionais da ordem econômica e social, sujeitando-a a observância da dimensão coletiva e de seus deveres ambientais. A consecução destes desígnios cujo teor define-se em leis próprias e encontra-se igualmente consubstanciada no art. $173 \S 1^{\circ}$ e inciso I da CRFB, é fiscalizada pelo Estado e pela Sociedade através das Agências Reguladoras ( como por exemplo Agência Nacional da Energia Elétrica- ANEEL, Agência Nacional de Petróleo-ANP, Agência Nacional de Telecomunicações- ANATEL).

\section{3) Propriedades Especiais Coletivas: patrimoniais (étnicas) e extra-patrimoniais (coletivas propriamente ditas).}

Trata-se aqui de um modelo de propriedade que foge do padrão anteriormente apresentado, no sentido de reconhecer a legitimidade de uma territorialidade por sua acepção histórica , antropológica e cultural. São três as espécies de propriedade que encontram-se sob esta categorização: a propriedade indígena, a propriedade quilombola e a propriedade de reserva extrativistas por populações tradicionais. Trata-se da preservação de

\footnotetext{
${ }^{68}$ E como tratam também os artigos 20 incisos V, VIII e IX e o art. 177 da CRFB.

${ }^{69}$ Dentre os exemplos citados pelo autor estão: o DL 227 de 1967 (Código de Minas); Lei n. 7.781/89 (minerais nucleares e derivados); Lei n. 9.478/97 (política energética nacional e atividades relativas ao monopólio do petróleo); Lei n. 8.901/94 (extração seletiva de madeira em florestas públicas); (lei 11.284/2006 (participação do proprietário do solo nos resultadas da lavra); a Lei 9433/97 (que institui a política nacional de recursos hídricos).

${ }^{70}$ Art. 1473 inciso V C/c 1230 do CC/2002.
} 
culturas diversas, de saberes e costumes de grupos étnicos distintos, cuja proteção merece tutela e reconhecimento Estatal. As propriedades quilombolas e indígenas conquistam sua legitimidade através do reconhecimento da existência de uma dívida histórica, tendo em vista os prejuízos trazidos a estas comunidades no processo civilizatório, e o reconhecimento da importância de se preservar modos de vida tão distintos, defendendo-se a multiculturalidade, tão presente na história e na identidade Brasileira.

Distancia-se portanto do padrão do direito administrativo que regula a propriedade pública e do direito civil que regula a propriedade privada, pois possui regime jurídico especial, com diferenças quanto ao modo de aquisição, gestão e tutela dos direitos a ela imanentes, que por sua vez diferenciam-se entre si quanto a suas peculiaridades e especificidades.

Os direitos relativos ao povo indígena são respaldados constitucionalmente, havendo igualmente a previsão do respeito a seus direitos em diversas Convenções Internacionais ratificadas pelo Brasil ${ }^{71}$.

Em defesa das comunidades indígenas, atua a FUNAI- Fundação Nacional do Índio ${ }^{72}$ que estabelece e executa a política indigenista brasileira e presta inclusive, assistência jurídica inerentes ao regime tutelar do índio.

A propriedade indígena é regulada pelo Estatuto do Índio, Lei 6001 de 1973, e as terras habitadas pelos indígenas estão sujeitas, pelo que dispõe o Código Florestal $^{73} \mathrm{em}$ seu art. $2 \S 2^{\circ}$, ao regime de preservação permanente. Seu reconhecimento encontra respaldo Constitucional no art. 231, que dispõe que "São reconhecidos aos índios sua organização social, costumes, línguas, crenças e tradições, e os direitos originários sobre as terras que tradicionalmente ocupam, competindo à União demarcá-las, proteger e fazer respeitar todos os seus bens". Outra peculiaridade existe no

\footnotetext{
${ }^{71}$ Dec. n. 58.824/68 Convenção 107 da OIT tratando da propriedade indígena; Convenção 169 da OIT sobre povos indígenas e tribais em países independentes - ratificada em 2002, Dec. Leg. 143/2002 e a Convenção da UNESCO sobre a diversidade das expressões culturais, Decreto Legislativo n. 485/2006.

${ }^{72}$ Instituída pela Lei 5371 de 1967.

${ }^{73}$ Lei 4771 de 1965.
} 
tocante ao regime jurídico da propriedade indígena que não é de domínio, e sim de posse permanente, com usufruto exclusivo das riquezas do solo, dos rios e dos lagos.

Cita José Pilati as dificuldades e impasses de questões que perduram até os dias de hoje, e que dizem respeito ao uso das terras indígenas quanto ao uso das riquezas e dos potenciais de energia hidráulica. A exploração de tais potenciais depende de autorização do Congresso Nacional, e a pressão e os interesses daqueles que querem se apossar de tais potenciais tem gerado um enorme impasse na questão das demarcações das terras indígenas, notadamente do citado caso da Reserva Raposa Serra do Sol.

Por sua vez, as propriedades quilombolas são descritas por Pilati como sendo aquelas:

\footnotetext{
"remanescentes das comunidades dos quilombos os grupos étnico raciais, segundo critérios de autoatribuição, com trajetória histórica própria, dotados de relações territoriais específicas, com presunção de ancestralidade negra relacionada com a resistência à opressão histórica sofrida. É propriedade coletiva, que inclui direitos culturais, cujas manifestações devem ser protegidas pelo Estado." 74
}

As propriedades quilombolas foram instituídas em diversos dispositivos legais $^{75}$ que reconhecem e a categorizam como uma comunidade local, sendo "um grupo humano distinto por suas condições culturais, que se organiza, tradicionalmente, por gerações sucessivas e costumes próprios, e que conserva suas instituições sociais e econômicas"76. Reconhece-se a importância histórica e cultural de tais comunidades ao decretar-se o tombamento dos sítios detentores de reminiscências históricas dos antigos quilombos, como o dispõe o art. $216 \S 5^{\circ}$ da CRFB. Possuem instituição própria, a Fundação dos palmares, que cuida de manter um cadastro geral das comunidades quilombolas, do acompanhamento dos processos de titulação e de tombamento e da defesa e articulação de seus interesses frente a terceiros ou frente a órgãos estatais.

\footnotetext{
${ }^{74}$ PILATI, José Isaac. Op. cit., p.22 e art $2^{\circ}$ do Decreto 4887/2003.

${ }_{75}^{75}$ Art.60 do ADCT c/c art. 215 e 216 da CRFB, bem como o já citado decreto 4887 de 2003.

76 PILATI, José Isaac. Op. cit., página 22.
} 
As propriedades quilombolas distinguem-se das propriedades indígenas, tendo em vista que o art. 68 do ADCT determina que sejam reconhecidas a propriedade definitiva destas terras (e não a posse) devendo o Estado emitir os devidos títulos de propriedade. De outra parte, seu regime jurídico distingue-se por tratar-se de uma propriedade dominial titulada, não havendo que se falar em usufruto como no caso indígena. Ademais, seu reconhecimento depende da própria comunidade, enquanto sua delimitação, demarcação e titulação competem ao Ministério do Desenvolvimento Agrário e ao INCRA, com competência concorrente dos Estados, Distrito Federal e Municípios ${ }^{77}$. Ponto importantíssimo que deve ser destacado, a titulação é feita mediante a outorga de título coletivo e próindiviso, em que consta cláusula de inalienabilidade, imprescritibilidade e impenhorabilidade, sendo o título cedido em nome da associação constituída pela comunidade.

A implementação do processo para aquisição da propriedade conta com instrumentos participativos, como o Plano Participativo, que garante aos representantes da comunidade o acompanhamento das diversas etapas até a aquisição, e após, para a gestão e tutela da propriedade.

Tem, portanto, caráter especial pois suas características e seu exercício são estabelecidos pela própria comunidade por meio de instrumentos de participação. Uma vez investidos, o regime jurídico atribuído à propriedade quilombola torna a área imune a qualquer perda por outro título de direito comum, como o usucapião.

As propriedades coletivas extrativistas são aquelas que integram o SNUC- Sistema Nacional de Unidades de Conservação da Natureza, e tratam-se em verdade de áreas de domínio público transformadas por iniciativa Estatal em Unidades de Conservação do Grupo de Uso Sustentável, estabelecidas estas por critérios definidos na Lei ${ }^{\circ} 9985$ de 2000. Garante-se através de seu estabelecimento não o domínio, mas a

\footnotetext{
${ }^{77}$ Art. $3^{\circ}$ do Decreto 4887 de 2003.
} 
posse e o uso dos recursos naturais de forma limitada e sustentável. As atividades são reguladas por contratos firmados com autoridades competentes, e tem por objetivo garantir os meios de vida destas populações, garantindo ao mesmo tempo a sustentabilidade do meio em que vivem. A propriedade extrativista como define Pilati:

"é propriedade coletiva, de cunho étnico, incidente sobre patrimônio nacional, instituída por lei, de conteúdo fixado em contrato coletivo, com participação popular, e que visa a compatibilizar biodiversidade, sociodiversidade e desenvolvimento sustentável, no contexto regional (...) é propriedade coletiva procedimental patrimonial." ${ }^{\text {78 }}$

${ }^{78}$ PILATI, José Isaac. Op. cit., página 26. 


\section{V. "As propriedades" e a manutenção do binômio público- privado.}

Apresentamos as mais diversas classificações das propriedades especiais que surgem na "pós modernidade", propostas estas por Pilati. Estas "propriedades especiais" estão imbuídas pela lógica da função social da propriedade, e possuem instrumentos participativos de tomada de decisão que garantem uma gestão mais democrática destes novos institutos. Isto permite-nos afirmar que sob esta lógica, não há mais que se apontar para a existência de "uma propriedade", pautada esta na lógica individualista, e sim em "propriedades" diversas criadas e moduladas para cumprir uma função social e atender aos anseios sociais de participação e de gestão democrática, a partir de instrumentos constitucionais, das leis de natureza participativa e de contratos coletivos. Contudo, em que medida podemos afirmar que a propriedade foge da lógica mercantil na qual está inserida? Em que ponto podemos afirmar que estas novas propriedades fogem do já citado construtivismo histórico que pauta-se no binômio público-privado?

O próprio autor defende que em verdade, há sim uma relativização do objeto de propriedade, do indivíduo como único interlocutor, e do próprio conteúdo do Direito que passa a contrapor de um lado "o uso, gozo e disposição à mercê do voluntarismo individualista" e de outro "a dependência de procedimentos e de decisões compartilhadas" ${ }^{\text {,79 }}$. Há portanto uma relativização, na medida em que foram inseridos mecanismos de participação e gestão destas novas formas de propriedade, mas a propriedade enquanto tal, com seus valores, permanece. Pilati assim discorre, alegando que as propriedades especiais:

"rompem com a autorreferencialidade da propriedade moderna codificada e seu sistema político institucional, relativizando os seus elementos, o que não significa a sua

79 PILATI, José Isaac. Op.cit. p.10. 
eliminação, como destaca Rodotá: a propriedade, com sua lógica sempre será o único, verdadeiro princípio e valor constitutivo de todo o sistema. Não só na modernidade, mas também na pós-modernidade. Os valores proprietários permanecem." 80

Não há assim uma superação do paradigma do binômio Publico X Privado, o qual já fora explicitado em capítulo próprio e o sobre o qual já apresentamos as bases históricas em que fora construído, uma vez que a propriedade permanece, mesmo que sob outras formas de gestão e de categorias jurídicas, seguindo os mesmos valores que a instituíram. Não há igualmente uma ruptura com os "valores proprietários" que constituem seu núcleo, não há ruptura com a "mentalidade proprietária": sua lógica mercantilista, que submete a propriedade a interesses privados, mesmo que "relativizada e limitada", permanece.

Mesmo frente às lutas e conquistas que levaram ao advento do Estado do Bem Estar Social no século XX, o conceito de propriedade não perde o caráter de um direito essencialmente individual. As recentes transformações relativizaram e transformaram o conceito de propriedade no plano jurídico, passando a dar a propriedade privada uma destinação econômica que age "apenas" sob uma "limitação"; a de garantir não só o bem do proprietário, mas também o bem da coletividade. Esta limitação é igualmente sentida por Hardt e Negri que assim discorrem:

\begin{abstract}
"Finally, with the construction of the welfare state in the first half of the twentieth century, public property gains a more important role in the republican constitution. This transformation of the right to property, however, follows the capitalist transformation of the organization of labor, reflecting the increasing importance that public conditions begin to exert over the relations of production. Despite all the changes, the old dictum remains valid: l'esprit des lois, c'est la propriété..."
\end{abstract}

Esta lógica leva ao pertinente questionamento de Rodotá, transcrito no texto de Pilati e que se reflete nas seguintes palavras:

"as dimensões de tal cidadania moderna dependem dos bens que cada um pode adquirir no mercado ou justamente do reconhecimento de uma série de situações jurídicas que

\footnotetext{
${ }^{80}$ PILATI, José Isaac. Op.cit. p.10.

81 HARDT, Michael; NEGRI, Antonio. Op.cit p. 48.
} 
livram o cidadão da lógica mercantil?",82

Em outras palavras, a consecução dos direitos deve necessariamente passar pela propriedade, ou os direitos são adquiridos e usufruídos de outras formas que fogem da limitada concepção da propriedade? Neste ponto, remetemo-nos ao questionamento de Pilati:

\begin{abstract}
"Ora, esse aspecto é nuclear à função social da propriedade: seria ela solidariedade social do proprietário privado ou, mais do que isso, o confronto da propriedade com direitos fundamentais elevados ao mesmo status de direito subjetivo, na pele de uma nova propriedade, a Propriedade Coletiva Extrapatrimonial?" 83
\end{abstract}

A última espécie de propriedade apresentada por Pilati é a propriedade coletiva extrapatrimonial, que representa segundo este autor uma quebra de paradigma, uma vez que "redimensiona quantitativa e qualitativamente a propriedade, porque significa romper o nexo propriedade-personalidade". ${ }^{84}$ Segundo o autor, dentro deste novo conceito de propriedade, as relações existentes entre indivíduos e bens deixa de ser "necessariamente mediada pela lógica individualista".

Partindo desta nova premissa, pautada em um novo significado que baseia-se relações que fogem desta lógica individualista e mercantil, abre-se um novo horizonte no qual podemos repensar não só novas formas de propriedade, mas também novas formas de relacionamentos sociais e quisá, novas formas de estruturas econômicas e políticas.

Assim defendem igualmente Hardt e Negri:

"Our critique of capital, the republican constitution, and their intersection as transcendental forms of power does not imply either absolute rejection or, of course, acceptance and acquiescence. Instead our critique is an active process of resistance and transformation, setting free on a new footing the elements that point toward a democratic future, releasing, most significantly, the living labor that is closed within capital and the multitude that is corralled within its republic. Such a critique thus aims at not a return to the past or creation of a future exnihilo but rather a process of metamorphosis, creating a new society within the shell of the old.", 85

\footnotetext{
${ }^{82}$ PILATI. José Isaac. Op.cit. p.27.

${ }^{83}$ PILATI, José Isaac. Op. cit., p.27.

${ }^{84}$ PILATI, José Isaac. Op. cit., p.27.

85 HARDT, Michael; NEGRI, Antonio. Op.cit p.8.
} 


\section{Os Bens Comuns.}

Como constatamos, a propriedade privada em sua acepção moderna e pós-moderna reproduz de certa forma uma natureza inerente a uma lógica mercantilista. Muita embora a lógica da "função social" e as novas categorizações, "as propriedade especiais", apresentem uma "nova era", esta concepção de propriedade apresenta seus limites se almejarmos uma sociedade realmente democrática e justa. Para alcançarmos nosso objetivo é preciso ir além, e aqui ressaltamos o momento de ruptura deste trabalho. Para repensar a propriedade, devemos nos livrar de nossa "mentalidade proprietária" e buscar as formas concretas com as quais se exterioriza a propriedade, seu "complexo sistema de situações reais" como afirmava Grossi.

Os bens comuns surgem como uma alternativa ao modelo de propriedade existente, apresentando um novo patamar de relações e de gestão de bens baseados em uma construção que foge da lógica mercantil imposta pelo modelo capitalista. Se a propriedade pode ser entendida como um parâmetro para se medir a realidade, uma vez que pauta a relação do homem com relação às coisas que o cercam, repensar a propriedade não se restringe apenas a uma "re-conceituação". Repensar a propriedade significa repensar os meios pelos quais são construídas as relações entre as pessoas, entre o homem e as coisas, entre o homem e sua capacidade produtiva, e isso implica em repensar como estas relações são construídas e organizadas.

Desta forma, devemos partir de uma premissa: a de que os bens comuns apresentam uma dificuldade em serem sintetizados em um simples conceito que se contraponha ao da propriedade privada, uma vez que são diversas as acepções que este conceito pode tomar. Muitos são os autores que se debruçaram sobre o tema, que apresenta uma gama de variações quanto a sua abordagem e tratamento. Trata-se de fato de um tema complexo e cientes deste fato, buscaremos expor sob diversos olhares as diferentes formas com as quais os bens comuns são tratados. 
Em um primeiro momento buscaremos demonstrar como, sob a ótica de J. Martin Pedersen, os bens comuns traduzem-se em relações sociais. Após este primeiro avanço visitaremos a obra de Lucarelli, que aponta os bens comuns como aqueles necessários a satisfação de nossos direitos mais elementares. Para garantir a correta gestão destes bens, afirma, devemos repensar em novas formas políticas que coloquem estes bens sob a tutela de todos. Este pensamento nos leva ao trabalho de De Angelis, que vê os bens comuns como "força política", e enxerga no "comum" uma verdadeira riqueza.

Ao percorrermos este caminho, concluiremos com base no trabalho de doutorado desenvolvido por Alexandre F. Mendes, e em uma síntese de todos os pensamentos que iremos expor, que os "bens comuns" e o "comum" apresentam-se como verdadeiras forças emancipadoras: o reconhecimento de nossa potência que nos conduzirá a um mundo mais justo e igualitário.

\section{A. Os bens comuns como relação social.}

J. Martin Pedersen, escreve um artigo para a revista virtual "The Commoner" ${ }^{\prime \prime 6}$, em que trata do tema da propriedade e dos bens comuns.

Defende Pedersen que em verdade, a propriedade é constituída por "protocolos normativos" que estruturam as relações sociais em relação as coisas, ou seja, relações proprietárias, e discorre alegando que:

"Given that there are, in practice, no social relations that do not involve things of some kind, as their setting or as their props, property is of fundamental importance to the way in wich societies, and other social groups are organized. Property protocols refer to customs, norms and conventions guiding people's behaviour". 87.

86 PEDERSEN, J.Martin, "Property, Commoning and the Politics of Free Software", The Commoner $\mathrm{n}^{\circ} 14$, Winter 2010, disponível em : http://www.commoner.org.uk/?p=107 acessado em 20/10/2013.

${ }^{87}$ PEDERSEN, J. Martim, Op.cit., p 140. 
Assim, a compreensão das formas de propriedade necessariamente passa por uma compreensão de como se estruturam as relações que são constituídas através diferentes tipos de propriedade. Colocadas neste mesmo "patamar", poder-se-ia compreender os métodos pelos quais a propriedade privada opera, e isto facilitaria uma transição para os bens comuns, "na transferência de terras, seus recursos e os meios de produção e distribuição" $" 88$.

Para uma melhor compreensão do método de análise empreendido por Pedersen, vamos contrapor as configurações relativas a propriedade privada, a propriedade pública e os bens comuns propostas pelo autor.

Em ambas as formas, o autor concentra-se em um pressuposto: a de que o uso e o acesso são os elementos centrais das relações sociais que dizem respeito as relações proprietárias. E Pedersen explica-se: o uso de privilégios baseia-se no acesso e no uso dos recursos que se tem das coisas. Em última instância, aquele que tem acesso decide que fim dar a coisa. Assim, pode-se dividir a função da propriedade em duas facetas: a do poder de controle ("control power") e o acesso a que se tem aos recursos ("usepriveleges"). ${ }^{89}$

A propriedade privada, tratada por Pedersen, assemelha-se em absoluto a propriedade napoleônica e absolutista já tratada neste trabalho. Neste modelo, tanto o poder de controle quanto o acesso ficam subordinados as decisões de uma pessoa, detentora de um título que é "autorreferenciado em termos de sua legitimação" 90 : a propriedade privada autoriza a pessoa a usar destas prerrogativas simplesmente de acordo com seu próprio interesse.

Este interesse é protegido pelo que Pedersen chama de "trespassory rules", que são as normas sociais e a proteção legal que impedem que pessoas alheias usem ou acessem bens que estejam sob o controle e o

\footnotetext{
${ }^{88}$ PEDERSEN, J. Martim, Op.cit., p 140.

${ }^{89}$ PEDERSEN, J. Martim, Op.cit., p 178.

${ }^{90}$ PEDERSEN, J. Martim, Op.cit., p 178.
} 
acesso de um proprietário sem seu consentimento. Tem-se assim um verdadeiro "reino", um território real que pode ser estendido ao contexto da propriedade de terras, cuja proteção legal fortifica as suas cercas excludentes $^{91}$. A problemática surge no mesmo sentido de nosso trabalho e do panorama histórico que traçamos: o bem-estar ("care") fica de fora da equação da relação indivíduo-propriedade. O próprio autor defende tal visão, admitindo que "unless decision making authority is legitimated by reference to something else than mere self-seekingness, care cannot adequately be accounted for on this model." $92 \mathrm{O}$ autor coaduna com o que apontamos igualmente, em capítulo próprio, ao salientar que em tal modelo de propriedade o indivíduo torna-se a fonte de toda a legitimidade da propriedade uma vez que transforma sua vontade em direito. ${ }^{93}$

A propriedade apresentar-se-ia assim, segundo esta ilustração proposta pelo autor:

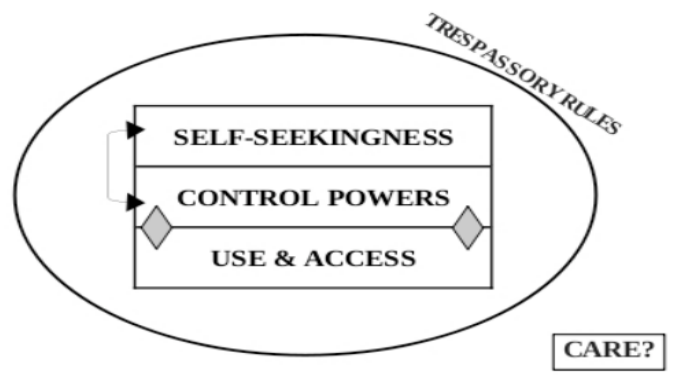

Illustration 2: Basic configuration of private property.

A propriedade pública por sua vez, distancia-se da propriedade privada neste aspecto, uma vez que coloca a função social ( "social interest/ care") juntamente aos poderes de controle e acesso, e a redistribuição legitima-se em um interesse diferente do individual, o interesse da coletividade. A ilustração assim a representa:

\footnotetext{
${ }^{91}$ PEDERSEN, J. Martim, Op.cit., p 179.

${ }^{92}$ PEDERSEN, J. Martim, Op.cit., p 180.

${ }^{93}$ PEDERSEN, J. Martim, Op.cit., p 180.
} 


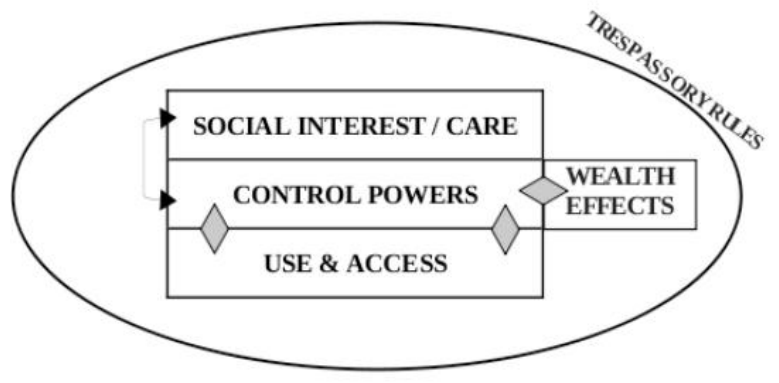

Illustration 5: Basic configuration of public property

Outras porém, são as justificativas que dão legitimação aos bens comuns, na medida em que seu reconhecimento parte do pressuposto de que existe uma relação ambivalente entre a propriedade e as comunidades: a de que não só as relações proprietárias formam uma comunidade, como as comunidades também formam relações proprietárias. Os bens comuns devem responder a dois questionamentos centrais, que permeiam as relações sociais: como se dá a distribuição da autoridade no que tange a tomada de decisões ("who?"), e que normas e valores vão pautar as tomadas de decisão (“how?”).

Os bens comuns, sustenta o autor, podem ser defendidos como uma configuração de propriedade autônoma. A autonomia, alias, é um dos elementos centrais de seu enfoque, uma vez que constitui o cerne do que representa o comum:

\footnotetext{
"Those who can collectively self-constitute form autonomus communities. Commoning is such collective self-constitution, commoning is creating autonomy. It is in the process of self-constitution that a certain kind of force of law is unleashed which binds the collective together. What binds us together is our common values, emerging, as they do, from commom action, co-habitation, communication, sociability. And it is from the collectivity that answers to how, who and what emerge, are contested, entrenched and overthrown". ${ }^{94}$
}

A ideia de comum repousa não em uma resposta dada, e sim em uma contínua construção, representada por valores distintos daqueles que pautam a propriedade privada, e que assim apresentam-se:

\footnotetext{
${ }^{94}$ PEDERSEN, J. Martim, Op.cit., p 204.
} 


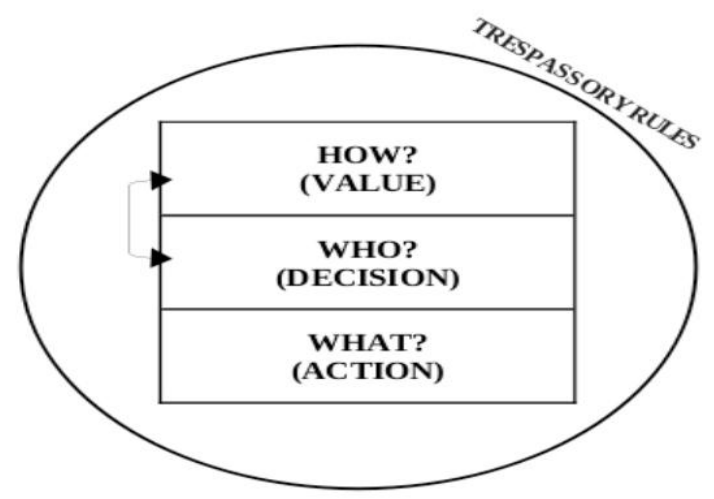

Illustration 6: Elementary questions of property.

Assim, podemos fazer um paralelo com os pensamentos apresentados por Paolo Grossi quando este tratava da propriedade medieval; é a de que o comum constitui-se a partir de uma série de "situações reais", constitui-se através de "relações puras", autônomas. Não há assim, que se falar de um conceito de comum contraposto ao conceito de propriedade privada, e sim em um processo de contínua construção, luta, descobrimento e emancipação. Se antes a propriedade introjetava-se subjetivamente na figura de um indivíduo proprietário, cabe agora a este indivíduo reconhecer seu potencial:

\footnotetext{
"The commoners body is autonomous from the state, her privileges and powers, rights and duties are laid upon the land and emerge and are reproduced through social interaction". ${ }^{95}$
}

\section{B. Os Bens Comuns como elementos essenciais a consecução dos direitos fundamentais.}

Frente a já discutida questão da dificuldade de se ultrapassar a dicotomia existente entre a propriedade Pública e a propriedade Privada, os

\footnotetext{
${ }^{95}$ PEDERSEN, J. Martim, Op.cit., p 204.
} 
bens comuns possuem um papel fundamental para se entender a lógica pela qual se opera a sua apropriação, e a necessidade de sua manutenção. Buscamos aqui apresentar as diferentes propriedades especiais, apresentadas sob conceituação proposta por José Pilati, e apresentamos suas peculiaridades a fim de se determinar em que ponto esta categoria de propriedade está sujeita a lógica mercantil inserida baseada nesta dicotomia, incluindo-as em um sistema que privilegia a apropriação por parte do capital privado.

Alberto Lucarelli escreve texto de fundamental importância para esta transição que se afigura ${ }^{96}$, e alerta que nos dias de hoje existem dois fenômenos que merecem especial atenção: a fragmentação do interesse público, e a privatização dos bens antes pertencentes a uma coletividade.

Frente a estas problemáticas, propõe Lucarelli que repensemos um sistema de direito público que enquadre novas categorias jurídicas, econômicas e sociais. Um dos sistemas que propõe baseia-se no requestionamento do conceito de propriedade baseado no conceito de "domínio" e nas relações que este implica entre o bem e seu proprietário, assim desconstituindo os valores tradicionais que permeiam a propriedade, refletindo sobe um percurso que conduza do bem público ao bem comum.

Propõe o autor este percurso, pois entende que devemos pensar em mecanismos que fujam da dicotomia da propriedade Público X Privada e da "propriété-gestion”, mecanismos estes que levem em consideração a manutenção dos bens coletivos em sua finalidade de origem, que é a satisfação dos bens fundamentais dos homens. Para tanto, propõe uma participação direta e ativa dos cidadãos: os mecanismos de controle para evitar a apropriação do público pelo privado devem vir de uma mobilização social. Destaca ainda o importante papel desempenhado pela Comissão

\footnotetext{
96 LUCARELLI, Alberto. “Au sein de la Constitution et au-delà de la Constitution. A la recherche de nouvelles dimensions de droit public : participation et biens comuns", Université de Naples, Federico II, sem data. Disponível em: http://seminaire.samizdat.net/IMG/pdf/contrbution_albertolucarelli.pdf acessado em 20/10/2013.
} 
Rodotá, que reconhece pela primeira vez a importância de se repensar o conceito de bem público, e de se pensar em uma nova categorização de bens que fogem da dicotomia Público X Privada ${ }^{97}$, na medida em que se reconhecem sua importância para a consecução dos direitos fundamentais do homem. Para tanto, apresenta-nos a importância dos bens comuns, os quais qualifica como aqueles definidos pela comissão em seu art. $1^{\circ}$ parágrafo $3^{\circ}$, item “c”" como sendo:

c) Introduction of the category of "common goods", that is things that are functional to the exercise of fundamental rights and to a free development of human beings. Common goods should also be protected by the legal system to the benefit of future generations. Holders of common goods can be either public or private legal persons. In any case they should guarantee the collective fruition of common goods in the ways and within the limits established by the law. If the holders are public legal persons, common goods are managed by public bodies and are located out of trade and markets; their concession/grant is allowed only in the cases provided by the law and for a limited time, with no possibility of extension. Examples of common goods are, among the others: rivers, streams, spring waters, lakes and other waters; the air; national parks as defined by the law; forests and wooden areas; mountain areas at a high altitude, glaciers and perpetual snows; seashores and coasts established as natural reserves; protected wildlife; archeological, cultural and environmental goods. The law concerning common goods should be in accordance with the existing customary law. Everyone is entitled to the jurisdictional protection of rights concerning the safeguarding and the fruition of common goods.

Os bens comuns representam assim, como bem define Lucarelli, em bens cuja titularidade, o controle, a posse e a gestão dizem respeito a uma coletividade e não a uma estrutura administrativa como o Estado. A legislação que regula estes bens deve basear-se em princípios fundamentais e partir da ideia de que são bens por definição indisponíveis, na medida em que são indispensáveis a satisfação das necessidades primárias de todos. ${ }^{98}$ Distancia-se assim, em ambas as facetas descritas, do conceito de propriedade especial apresentado por Pilati, uma vez que as propriedades especias são geridas através de instrumentos de direito administrativo, são muitas vezes bens de domínio público, e são intermediadas por instituições Estatais (INCRA, FUNAI etc...).

\footnotetext{
${ }^{97}$ A Comissão Rodotá reconhece em seu art. $1^{\circ}$ parágrafo $3^{\circ}$, item $\mathrm{b}$, os bens comuns como uma nova categoria de propriedade: "b) Establishment of three distinct categories of properties: common goods, public property, private property."

${ }^{98}$ LUCARELLLI, Alberto. Op. cit., p.2.
} 
Ugo Mattei, em entrevista dada a revista Le Monde Diplomatique, defende igualmente este ponto de vista e afirma:

\begin{abstract}
"Il importe donc de développer une élaboration théorique, accompagnée d'une défense militante, traitant les biens communs comme une catégorie dotée d'une autonomie juridique constituant une solution de rechange aussi bien à la propriété privée qu'à la propriété publique ." 99
\end{abstract}

Ambos os autores defendem que os bens comuns devem surgir como uma categorização que deve ser protegida da pilhagem conduzida pela iniciativa privada e o Estado Neoliberal, e que tal mudança se dá a partir de uma transformação do direito público, e de uma gestão que aprimora as instâncias democráticas de controle dos bens comuns. O Estado não mais serve como um gestor confiável destes bens, uma vez que, em última instância este acaba por ser apropriado pela iniciativa privada.

Uma gestão pública participativa daria aos bens comuns um reconhecimento, e seria de suma importância para separar os interesses da coletividade, efetivamente, daqueles empreendidos pela administração pública, que pode ser contaminada pelas vicissitudes do mercado. Lucarelli trata de tema especialmente atual e que pode ser constatado no Rio de Janeiro, ao alegar que o direito público, ao aproximar-se do direito privado, em regimes de concessão de serviços por exemplo, tende a afastar-se de sua finalidade de defesa dos interesses da coletividade para atender a interesses de determinados grupos econômicos. Denuncia assim a promiscua relação existente entre estas duas esferas, pregado uma distanciação que gere uma efetivação da vontade da coletividade e da satisfação das necessidades fundamentais. ${ }^{100}$

Defende assim novos mecanismos de tomada de decisão, baseados em modos de participação que incluam não somente partidos políticos e

\footnotetext{
${ }^{99}$ Ugo Mattei. "Rendre inaliénables les biens comuns" Le Monde Diplomatique, dezembro 2011. Disponível em http://www.monde-diplomatique.fr/2011/12/MATTEI/47058, acessado em 20/10/2013.

${ }^{100}$ LUCARELLI, Alberto. Op.cit., p 3.
} 
sindicatos, mas que busquem novas formas de representatividade junto a movimentos sociais e outras entidades representativas da sociedade civil.

Lucarelli repudia os novos estados pensados sob diferentes formas de assistencialismo, e defende que os bens comuns devem ser pensados em um contexto que foge das formas tradicionais de representação e soberania, abrindo-se a novas formas de representatividade e baseando-se em preceitos de direitos fundamentais mais universalistas. Defende em suma, uma participação difusa e livre, através de políticas públicas e de instrumentos participativos diretos que efetivamente garantam os bens comuns, concluindo que:

"Le passage du public au commun ne signifie pas réorganiser les espaces, mais plutôt enlever aux autorités politiques et administratives traditionnelles un monopole sur la gestion autoritaire de ces espaces, et les premières réussites de cette transformation pourraient concerner des formes expérimentales de gestion publique partagée et participative des biens communs." 101

\section{Os Bens Comuns e o "comum" como poder político.}

Neste ponto, gostaríamos de nos aprofundar no trabalho de Massimo De Angelis, que de certa forma sintetiza as duas vertentes dos bens comuns que acabamos de apresentar: de um lado o reconhecimento, assim como o faz Pedersen, da importância dos bens comuns enquanto relação social; de outro, a retomada do pensamento de Lucarelli, que traz a noção de bens comuns como bens essenciais, e mais importante, o aspecto político de seu discurso que defende que estes só são efetivamente garantidos através do reconhecimento do papel central daqueles que constituem o bem comum.

Fazendo um paralelo com o trabalho de Pedersen, De Angelis reconhece a importância do "use" e do "acess", e destaca aqui também a

\footnotetext{
${ }^{101}$ LUCARELLI, Alberto. Op.cit., p 6.
} 
ambivalência existente na relações proprietárias, e seu construtivismo:

\begin{abstract}
"Seizing power over our lives implies therefore not only being able to access resources and means of existence that enable us to organize social production, but also getting on with defending, building and transforming our communities. Indeed, commons and communities are two sides of the same coin." 102
\end{abstract}

A partir destes traços podemos dividir o discurso de De Angelis, se seguirmos a preocupação metodológica de Pedersen, nos três espectros (perguntas) que permeiam a funcionalidade todas as relações sociais: Quem? (“Who?”), Como? (“how?”) e O que? (“What?”).

De Angelis mostra primeiramente uma preocupação em situar o que considera como basilar para se estabelecer um discurso crítico sobre a atual conjuntura do capitalismo neoliberal: o reconhecimento da importância de uma política econômica globalizada e suas diferentes facetas, e a importância da participação (política) dos movimentos sociais que formam o movimento por uma "justiça global" ("global justice") e os movimentos de solidariedade.

"Movimento" destaca-se como uma das palavras centrais em seu pensamento, uma vez que defende que estes movimentos que lutam contra o capitalismo, seus processos sociais e seus esquemas, devem vir "de baixo". Aqueles que justamente se encontram excluídos dos processos apropriatórios engendrados pelo sistema capitalista devem constituir, através de praticas políticas efetivas e de suas lutas concretas, um novo mundo "que leve em conta as pluralidades sem impor velhos modelos ou reiterando ideologias já mortas". Só assim sera possível identificar e fazer um paralelo entre as implicações constantes nas lutas locais e aquelas constantes a nível global, a fim de que se constitua "um mundo onde

\footnotetext{
102 DE ANGELIS, Massimo. "Reflections on alternatives, commons and communities or building a new world from the bottom up". In: The Commoner n ${ }^{\circ} 6$ Winter 2003. Disponível em: www.commoner.org.uk/deangelis06.doc
} 
coexistam diversos mundos". 103

Parte igualmente do princípio de que, as soluções para fugir deste modelo imposto pelo capitalismo estão em todos lugar e são plurais, e que repousam nas próprias relações sociais ( apelidadas, em referencia a uma rede, de "nós sociais" ou "social nodes") do dia a dia, pois as alternativas encontram-se em cada indivíduo ou grupo de indivíduos.

Destacamos aqui, no discurso de De Angelis, a primeira das perguntas relativas ao trabalho de Pedersen, "How?":

\begin{abstract}
"Since every social node is aware of a spectrum of alternatives, the problem is simply how to make these alternatives actual? What resources are needed? How to coordinate alternatives in such a way that they are not pitted against each other as is the case of the competitive markets' understanding of alternatives? How to solve the many existing problems without relying on the alienating coordinating mechanism of the market and creating instead social relations of mutual enrichment, dignity, and respect? These are I believe the bottom line questions on which a new political discourse must be based." $" 104$
\end{abstract}

O discurso político de De Angelis baseia-se na ideia de que as alternativas são produtos da sociabilidade, e de que este discurso deve centrar-se em pensar em maneiras de coordenar estas alternativas a fim de que todos os indivíduos possam ter o poder de decidir e tomar o poder e o controle de suas vidas, dando reconhecimento e validade social a todo o processo. Isto pressupõe que pensemos para além das formas existentes de coordenação social, além da figura do Estado e das "mãos invisíveis que controlam a competitividade dos mercados", que se expressam através das politicas de governança neoliberais. O único jeito, para o autor, de se fortalecer as comunidades, é expandindo o espaço consagrado aos bens comuns. $^{105}$

De Angelis sustenta que tanto as enclosures como a competitividade existentes nas relações capitalistas devem ser superadas, e não ser consideradas como dogmas imutáveis. Devem sim servir de horizonte para as lutas, que devem pautar-se na praxis, em um processo circular de "cognição, refleção e imaginação" e de praticas efetivas de mudança no

\footnotetext{
${ }^{103}$ DE ANGELIS, Massimo. Op.cit. p.2.

${ }^{104}$ DE ANGELIS, Massimo. Op.cit. p.3.

${ }^{105}$ DE ANGELIS, Massimo. Op.cit. p.3.
} 
mundo. Não há, assim, uma resposta dada. ${ }^{106}$

Ainda no campo reflexivo do "How?", De Angelis separa em duas as formas de movimento que norteiam o campo de atuação que deriva destas novas formas de organização que irão surgir: a captura ("seizure") e/ou as demandas pelo comum, e o processo de aprendizado decorrente das comunidades. Ressalta mais uma vez a ambivalência existente nestas relações, alegando que "the organizational forms it practices, communities cannot be separated from the learning practices of direct democracy, horizontality, participation, and inclusiveness." ${ }^{107}$, resgatando de certa forma o que já havia intuído Lucarelli em seu trabalho.

Neste ponto, depois de estabelecer as bases de aproximação deste novo mundo através das praticas do comum, constituídas tanto através de praticas sociais como do reconhecimento dos desafios que se apresentam, partimos para os valores que de certa forma vão nortear esta atuação. Entramos aqui no campo do "O que?" ("What?”) para compreendermos melhor como De Angelis trata desta questão.

Neste grande emaranhado, nesta multiplicidade de alternativas que surgirão, o que servirá de base para guiar e organizar este movimento?

Primeiro, De Angelis aponta para a necessidade de um "mutual understanding of subject-positions”, ou seja, frente a diversidade e a pluralidade de ideais e valores, o "choque" de diferentes "mundos", devemos reconhecer que estamos nos constituindo enquanto "sujeitos sociais" e devemos respeitar "o outro", enquanto "sujeito social" e igualmente livre de expor suas opiniões.

Segundo, a de reconhecer este processo como um momento de construção ("self-construction"), e de que neste "caos" dos processos de constituição do comum, a semente, de novas formas de política estão sendo criadas. $^{108}$

\footnotetext{
${ }^{106}$ DE ANGELIS, Massimo. Op.cit. p.4.

${ }^{107}$ DE ANGELIS, Massimo. Op.cit. p.5.

${ }^{108}$ DE ANGELIS, Massimo. Op.cit. p.6.
} 
Para De Angelis, o reconhecimento de que nós naturalmente somos indivíduos sociais, faz deste processo de comunicação, deste processo de constituição do comum, algo irrefreável. Devemos pensar para além da lógica da organicidade Estatal e buscar no comum, constituído através de comunidades, suas trocas e suas potencialidades, as alternativas viáveis para este modelo mercantilista que nos é imposto.

\footnotetext{
"These human exchanges on the basis of commons are different from the current market exchanges grounded on enclosures that have come to dominate our lives." 109
}

A construção de um mundo novo passa por um processo de resistência contínua segundo De Angelis. Devemos atacar e contestar o cerne da mentalidade capitalista: a propriedade corporativa que dita os meios de existência, e que baseia nossas relações apenas na competitividade. Buscar novas formas de sociabilidade, pautadas em outros valores que fogem desta lógica meramente mercantilista, passa necessariamente pelo enfrentamento deste modelo.

\footnotetext{
“Capital, that depends on growth for growth's sake, barrier overcoming and colonization of life, collapses if it is unable to overcome the barrier posed by socialized humanity. We will have to take responsibility and say what must be said: the expropriators must be expropriated so that we can rebuild our lives through new forms of sociality. We will have to take responsibility and find ways to go beyond the invisible hand of the market and the visible fist of the state to coordinate our social practices." 110
}

De Angelis segue o entendimento de Lucarelli e de Pedersen ao afirmar que os bens comuns são aqueles cujo acesso (“acess") direto está intimamente ligado ao bem estar social, e de que há uma imensa tensão entre os bens comuns e o que denomina de "neoliberal capitalist enclosures". O autor defende que, é na luta contra os enclosures que se abre a questão dos comuns,e consequentemente, é nos comuns que se abre a questão sobre modelos alternativos, uma vez que os bens comuns

\footnotetext{
${ }^{109}$ DE ANGELIS, Massimo. Op.cit. p.6.

${ }^{110}$ DE ANGELIS, Massimo. Op.cit. p.7.
} 
representam um limite a apropriação por parte do capital. ${ }^{111}$

As alternativas devem ser pensadas fora das restrições impostas pela propriedade e pelas posições adotadas pelo lógica do mercado, pautando-se em uma lógica de cooperação, invenção e inovação que foge puramente da lógica do lucro. A organicidade destas novas relações sociais deve se libertar das amarras da dominação, exclusão e opressão impostas pelo capitalismo. Nas palavras do autor, esta nova organicidade deve reconhecerse como "potentia" que foge dos poderes capitalistas (ou "potestas"), que o condicionam. Destaca-se aqui a importância dada pelo autor de se enxergarem estas lutas como "um todo", inserindo aqui o conceito de "trans-localidade" que trataremos a seguir, e cuja importância é primordial na luta contra as cooptações do sistema capitalista.

Aqui, entramos na terceira e última pergunta, "Quem?" (“Who?”), uma vez que De Angelis centra a própria comunidade e seus indivíduos como principais agentes transformadores:

\footnotetext{
"Alternatives become actualised through the power of seizing control of our lives, of transcending alienation beginning from our life-worlds and spheres of action. Our lifeworlds define communities we belong to immediately, and these are nothing other than networks of real individuals, living real conditions, having real needs and aspirations and enjoying real relations among them."112
}

Duas são as esferas que De Angelis analisará neste ponto: o conceito de translocalidade, e o potencial transformador das comunidades. Primeiramente, é importante definirmos o que o autor entende como comunidade. As comunidades são, para De Angelis, como redes sociais de ajuda mútua, solidariedade e práticas de troca humana, espaços onde se sustentam relações que não se baseiam na competitividade e aonde toda ação social constitui uma potência. Ressalta o autor, que não são propriamente os objetos ou os elementos comuns que constituem uma comunidade, mas sim as relações que as constituem, reforçando ainda que,

\footnotetext{
${ }^{111}$ DE ANGELIS, Massimo. Op.cit. p.8.

${ }^{112}$ DE ANGELIS, Massimo. Op.cit. p.10.
} 
sob nenhum pretexto, esses valores devem pautar-se na competitividade.

Em um ambiente de competitividade, explica, sempre haverá aquele que perde e aquele que ganha. Permanecer nesta dicotomia é aceitar a perpetuação de um modelo que, por definição, é composto por uma eterna oposição. ${ }^{113}$

Temos então um cenário composto por duas esferas distintas: a primeira na qual repousa a comunidade intralocal e sua lógica de cooperação social e de outro a negação e a apropriação destas comunidades pelas relações de mercado. O discurso político de De Angelis pauta-se justamente na superação deste cenário, ao propor um crescimento dos bens comuns que confronte o modelo mercantil pautado na competitividade.

Para traçar este caminho, o primeiro passo proposto pelo autor é o reconhecimento de que a "localidade" de uma comunidade, como um espaço restrito de valores, lutas e reivindicações próprias deve ser abandonado. Deve reconhecer-se que, por mais isolada que seja, toda comunidade faz parte de um "todo" uma rede translocal de relações sociais ("trans-local network of social relations"). Desta forma, e reconhecendo esta interdependência, a dificuldade reside em pensar-se nesta rede sem que esta interdependência reproduza as mesmas formas de competitividade já existentes. O novo discurso político deve partir do princípio de que existe uma responsabilidade justaposta entre os indivíduos e as comunidades no sentido de se perseguirem aspirações que fogem da lógica capitalista:

\footnotetext{
"We want the wealth of localized knowledge and localized traditions to be available to all. We seek patterns of trans-local human exchanges that enrich us all. We want ways that allow anybody and any local or trans-local community to "draw credit" from the "bank" of humain genuity, paying back to the world the innovation that always accompanies the adaptation of existing resources and knowledge to specific problems and circumstances." 114
}

O discurso político de De Angelis segue no sentido de que o Estado deve constituir-se não como uma entidade que age de maneira vertical, mas

\footnotetext{
${ }^{113}$ DE ANGELIS, Massimo. Op.cit. p.11.

${ }^{114}$ DE ANGELIS, Massimo. Op.cit. p.12.
} 
sim como a "comunidade das comunidades", através de uma estrutura horizontal: quanto maior o poder decisório das comunidades, maior é a comunidade que surge de sua articulação ${ }^{115}$.

Desta forma, o autor acaba por definir em linhas claras a discussão que abordamos em capítulo próprio, quanto a necessidade de superação da figura do Estado como atualmente existente:

\begin{abstract}
"Instead of being the shadow of our social cooperation, it is the divisive knife with which to enforce competition in every sphere of life, thus breaking up communities. Instead of being a simple tool to help, facilitate and promote people to exercise their many powers, the state is the "power over" that channel these "powers to" into forms compatible with capital accumulation."116
\end{abstract}

O que se estabelece em linhas finais, é a eterna separação e disputa entre dois modelos, onde o capitalismo tenta, através da apropriação e da cooptação destruir tudo aquilo que é comum. A mudança passa então, necessariamente, pelo fortalecimento das comunidades e do reconhecimento da essencialidade dos bens comuns. De Angelis deixa-nos com a seguinte mensagem:

\footnotetext{
"Our movement of movements, in the articulation of all its dimensions and the innovative organizational forms it gives itself, has shown what these needs and aspirations are. These are social relations that are horizontal instead of being vertical, that are inclusive, instead of being exclusive, that promote empowered participation and dignity, instead of enforcing and promoting exploitation, oppression, estrangement and competition. In a word, a different world springs from a movement that practices what it preaches."117
}

\title{
D. O "comum" como poder emancipatório.
}

Chegamos ao final de uma jornada onde tentaremos sintetizar e conectar todos os pensamentos que permeiam a essência dos bens comuns, sob as diferentes óticas apresentadas. Sejam estes relações sociais, bens fundamentais ou poder político, os bens comuns representam sobretudo um

\footnotetext{
${ }^{115}$ DE ANGELIS, Massimo. Op.cit. p.13.

${ }^{116}$ DE ANGELIS, Massimo. Op.cit. p.13.

117 DE ANGELIS, Massimo. Op.cit. p.14.
} 
caminho que leva a libertação das amarras do capitalismo e da ditadura do mercado. Neste último capítulo, dedicamo-nos ao trabalho elaborado por Alexandre F. Mendes em sua tese de doutorado ${ }^{118}$, no qual concluímos que a mudança que desejamos passa por uma ruptura com as atuais instâncias de poder político, econômico e social.

Para definirmos as linhas com as quais partiremos, reportamo-nos aos dizeres de Hardt e Negri, que descrevem de forma sintética a atual conjuntura, e continuamos nosso caminho para além da dificuldade proposta por De Angelis, de superação da oposição entre "comunidade" e "apropriação":

\begin{abstract}
There has been a continuous movement throughout the modern period to privatize public property.(...) During the consolidation of industrial society, the construction and destruction of public spaces developed in an ever more powerful spiral. It is true that when it was dictated by the necessities of accumulation (in order to foster an acceleration or leap in development, to concentrate and mobilize the means of production, to make war, and so forth), public property was expanded by expropriating large sectors of civil society and transferring wealth and property to the collectivity. That public property, however, was soon reappropriated in private hands. In each process the communal possession, which is considered natural, is transformed at public expense into a second and third nature that functions finally for private profit.(...) Capitalism sets in motion a continuous cycle of private reappropriation of public goods: the expropriation of what is common. ${ }^{119}$
\end{abstract}

É neste cenário das "new enclosures"120, e dos processos de acumulação primitiva do capitalismo que estabelecemos nosso último ponto de partida. É importante salientar que Mendes consagra um capítulo de seu estudo à "Produção do Comum", e que muito embora utilize-se de um outro autor para estabelecer a base de sua abordagem sobre o antagonismo acima apontado, Jean-Luc Nancy, não há propriamente um distanciamento da visão que apresentamos, e sim diversos pontos em que estas perspectivas sobre o comum acabam por convergir. Destacamos assim alguns pontos que acreditamos ser pertinentes, e que servirão, nunca é demais, como forma de

\footnotetext{
${ }^{118}$ FABIANO MENDES, Alexandre. "Para além da "Tragédia do Comum": conflito e produção de subjetividade no capitalismo contemporâneo". Rio de Janeiro, Universidade do Estado do Rio de Janeiro - UERJ - Centro de Ciências Sociais e Faculdade de Direito, 2012.

${ }^{119}$ HARDT, Michael; NEGRI, Antonio. "Empire", Harvard University Press,Cambridge, Massachusetts/London, England, 2000. p. 301.

${ }^{120}$ F. MENDES, Alexandre. Op.cit. p.93.
} 
sintetizar a caminhada que realizamos até então.

Primeiramente, podemos estabelecer um paralelo sobre a noção de "comunidade perdida" e a ideia apresentada por De Angelis e por Lucarelli, de que a comunidade enquanto "união fusional de seus membros""121 é um ideal a ser atingido, e não propriamente um fim. Intuímos previamente, como o faz Nancy, que a comunhão é na verdade atividade, praxis, um processo cíclico de resistência como havia apresentado De Angelis.

Segundo, Mendes trata do conceito de "mundo compartilhado" presente na obra de Heidegger, onde coloca o indivíduo no centro de um mundo compartilhado com outros, no qual devemos abandonar a perspectiva da individualidade, do "ser comum" para o "ser em comum", assim como o faz

De Angelis, quando apresenta a ideia de "diversos mundos no mundo", também tratada por Nancy. Passamos assim a uma perspectiva que coloca o sujeito no âmbito de uma "existência compartilhada", e não "exclusiva".

A partir desta perspectiva, há a superação da compreensão dos bens comuns como meros bens ou recursos, e parte-se de uma perspectiva dos bens comuns como relações sociais (Pedersen) e como a própria essência da coexistência, que não pode ser mensurada (De Angelis).

Nos dizeres de Mendes, o comum é "produção social aberta ao infinito"; é "compartilhamento de mundo"; é coagulação entre "homem e natureza"; é um processo de diferenciação, de abertura singular que resiste a qualquer identidade, medida ou regra de comensurabilidade. " 122

Destacamos um ponto importantíssimo: a necessidade de considerarmos que "nada é equivalente". Aqui estabelecemos um paralelo entre a ruptura proposta por De Angelis, que prima por um mundo que fuja dos valores primados na competitividade imposta pelo capitalismo, e a de Nancy, onde as singularidades não podem ser reduzidas a uma "equivalência geral"123

\footnotetext{
${ }^{121}$ F. MENDES, Alexandre. Op.cit. p.131.

${ }^{122}$ F. MENDES, Alexandre. Op.cit. p.136.

${ }^{123}$ F. MENDES, Alexandre. Op.cit. p.137.
} 
Ambos primam pela produção daquilo que não pode ser mercantilizado, que não pode ser apropriado.

$\mathrm{O}$ "comum do comunismo" de Nancy assemelha-se ao "movimento dos movimentos" de De Angelis: as alternativas repousam para além das regras erigidas e das soberanias fabricadas, e na criação de um discurso político que se baseie "nos meios" e não "nos fins""124

Voltamos ao marco que já havíamos previamente estabelecido: não se trata aqui de uma resposta dada, mas das "condições ontológicas"125 para se pensar o "comum". Nancy portanto, encontra o mesmo obstáculo apresentado por De Angelis: embora reconheça-se a capacidade política dos bens comuns de "ativar" e "limitar" a política, trata-se aqui de uma précondição, anterior a própria política.

Para avançarmos em nossa caminhada devemos perseguir na leitura de Mendes e perceber que, para ultrapassarmos esta barreira, devemos abandonar este conceito de uma "ontologia primeira" e reconhecer que "o comum é produzido em uma dinâmica viva, em um feixe de relações de instável multiplicidade, que não excluem o comum, mas o fazem emergir na riqueza política das resistências". Não há assim uma pré-condição, recuperando o pensamento de Foucault, na medida em que a própria resistência é o processo primeiro que aproxima a política do comum ${ }^{126}$. Mendes resgata assim no pensamento de Negri a premissa de que em verdade, há "uma construção ontológica contínua e determinada do comum" que parte "da produção de subjetividade através da atividade social do trabalho", e que para reaproximar de fato o comum da política, devemos considerar "o comum como um verdadeiro processo antagonista inserido em uma relação conflitual entre a estrutura material de relações de produção de subjetividade através da atividade social do trabalho" 127

$\mathrm{O}$ amago da questão reside, finalmente, no que Mendes ressalta do

\footnotetext{
${ }^{124}$ F. MENDES, Alexandre. Op.cit. p.138.

${ }^{125}$ F. MENDES, Alexandre. Op.cit. p.139.

${ }^{126}$ F. MENDES, Alexandre. Op.cit. p.144.

${ }^{127}$ F. MENDES, Alexandre. Op.cit. p.145.
} 
pensamento de Rogerro como sendo as relações conflituosas entre o capital e o trabalho: o novo horizonte das relações sociais passa pelas formas de produção, atravessadas estas pelas recentes formas de exploração do capital.

Neste ponto identificadas as barreiras que nos impediam de progredir, e estabelecidas as novas premissas sob as quais estudaremos o comum, avançamos no último capítulo de Mendes, que trata da produção do comum como "processo antagonista".

Contrariamente a De Angelis que reconhecia a "potência" em qualquer relação social, Mendes destaca a visão de Negri que identifica o "trabalho vivo" como verdadeiro poder constituinte, onde se constitui a produção de uma "autonomia complexa" livre da exploração capitalista. ${ }^{128}$ A necessidade de se enxergar as relações conflituosas existentes entre o capitalismo e as forças de trabalho "como um todo", frente a nova multiplicidade de forças produtivas, dá nascimento a uma nova "classe trabalhadora" que foge do conceito do "operário-massa" e faz surgir o "operário-social"; um conceito que abarca as novas dimensões de produção social e leva em conta as novas instâncias de controle capitalista.

As "mil figuras" que surgem da socialização do "trabalho vivo" surgem também como uma nova potencialidade que, por sua ingerência ("a impossibilidade de realizar qualquer tentativa de organização direta da força produtiva") aparecem como novas instâncias para a produção do trabalho imaterial, do "saber social geral", na medida em que conflitam com o tempo de trabalho imposto pelo capital. ${ }^{129}$

Desta crescente emancipação, surgem novas formas de "cooperação social" que criam uma capacidade de organização produtiva que dispensa as formas tradicionais desenvolvidas pelo capital. É no terreno do "trabalho vivo" e "do saber social geral", e no reconhecimento de que deles decorre a produção da subjetividade, que repousam os novos horizontes de luta. Não há mais distinção entre produção e política, ponto em que estabelece-se

\footnotetext{
${ }^{128}$ F. MENDES, Alexandre. Op.cit. p.147.

${ }^{129}$ F. MENDES, Alexandre. Op.cit. p.149.
} 
uma nova ambivalência: "O trabalho devém ação política, na mesma medida em que a política é inseparável dos novos modos de produzir (subjetividade) no pós-fordismo". ${ }^{130}$

Partimos assim , para uma "análise do "comum" que tem como eixo o antagonismo entre capital e produção autônoma de subjetividade no horizonte da recente reestruturação do capitalismo". Este comum que se produz como um "conjunto de saberes, conhecimento, informações e imagens" constituirá uma "partitura comum" que possibilitará imaginarmos uma "esfera pública não estatal totalmente nova com relação às formas clássicas de democracia". ${ }^{131}$ As forças que porventura tentem administrar estas relações aparece como forma de servidão, estabelecendo assim um novo antagonismo que coloca de um lado "uma forma radicalmente nova de democracia" e de outro "a servidão virtuosística universal":

\footnotetext{
"Essa democracia radical, expressada na livre cooperação do "agir-de-concerto", depõe as antigas dicotomias modernas de "público-privado", de "indivíduo-coletivo" ou de "cidadão-produtor". A cooperação social baseada no general intellect só pode dar lugar a uma "esfera pública" que relacione uma multiplicidade (os "Muitos") a uma "partitura comum" que se recusa a qualquer tipo de "contrato social", delegação de poder, ou convergência em uma abstrata "vontade geral": "os Muitos não fecham acordos, nem transferem direitos ao soberano, porque já dispõem de uma "partitura" comum: não convergem nunca em "volonté générale" porque já compartilham o general intellect". 132
}

Restam assim evidenciadas as novas diretrizes do "comum" que devem emergir tanto da cooperação social pós-fordista, como da não distinção entre ação e trabalho, entre práxis política e atividades humana, entre liberdade política e emancipação econômica. Estas diretrizes, no entanto, não bastam para concluirmos nossa jornada, uma vez que Mendes refere-se a preocupação exposta por Hardt e Negri de que esta perspectiva do "trabalho vivo" acabe por limitar-se a seus aspectos unicamente "intelectuais e incorpóreos". Para fugir de um terreno puramente teórico, "linguístico" e "cognitivo", busca-se agregar elementos corpóreos, "somáticos" e afetivos que concentram-se em um novo conceito: a de

\footnotetext{
${ }^{130}$ F. MENDES, Alexandre. Op.cit. p.151.

${ }^{131}$ F. MENDES, Alexandre. Op.cit. p.154.

${ }^{132}$ F. MENDES, Alexandre. Op.cit. p.156.
} 
"produção biopolítica”. O conceito de biopolítica abarca não somente o elemento da "inteligência social”, mais inclui também as "expressões afetivas que definem as relações sociais e governam as articulações do ser social", assim constituindo-se de uma conjunção entre "corpo e cérebro", “inteligência" e "afeto", "produção" e "vida". 133

Neste ponto do trabalho, estabelecemos a relação final entre o antagonismo apresentado como ponto de partida: a produção do comum, vista sob esta nova perspectiva, e o fenômeno da apropriação primitiva do comum por parte do capital, os "new enclosures". É neste ponto de tensão que um "projeto político" precisa ser pensado, projeto este em que:

\footnotetext{
"O "poder comum", a expansão do trabalho como ação política, deve, portanto, assumir uma forma antagonista, baseada em sua capacidade de autovalorização e autonomia, e "reapropriar" tudo aquilo que foi expropriado pela universalização da propriedade privada". ${ }^{134}$
}

Este processo de reapropriação do comum é realizado por um novo "sujeito político": a multidão. A multidão caracteriza-se aqui como um "sujeito complexo que se constitui na cooperação", mas que vai além da simples dimensão economicamente produtiva, e apresenta-se como "a potencia das singularidades de expressar-se em todas as direções, de mostrar-se como proliferação da liberdade", potência esta imersa no conceito de biopolítica. ${ }^{135}$

A multidão como "conjunto de singularidades" se apresenta como uma nova instância de liberdade, não se reduzindo as figuras identitárias dos "indivíduos apropriadores", mas apresentando-se como um duplo movimento: a recusa a esta identidade (êxodo), e a produção baseada na vida (biopolítica). A multidão aproxima-se do comum na medida em que se constitui através destas práticas de liberdade que proporcionam uma produção de “subjetividade na multiplicidade". É esta "produção de

\footnotetext{
${ }^{133}$ F. MENDES, Alexandre. Op.cit. p.157.

${ }^{134}$ F. MENDES, Alexandre. Op.cit. p.155.

${ }^{135}$ F. MENDES, Alexandre. Op.cit. p.161.
} 
diferença" que se torna o novo meio de disputa do capital, que busca a apropriação desta "riqueza social": não é somente o tempo de trabalho excedente que é expropriado mas todo o conjunto produtivo e vivo das relações sociais, afetivas, comunicacionais, cooperativas, cognitivas, imateriais etc...O novo horizonte da "acumulação primitiva social", o comum, torna-se o objeto da exploração do capitalismo contemporâneo, como veremos a seguir. ${ }^{136}$

Esta expropriação é expressa sem ambiguidades por Negri e Hardt, e Mendes destaca que para os autores: "a produção do comum se torna um projeto político que ataca tanto a privatização neoliberal quanto as expropriações estatais". Afirma igualmente, assim como o fizemos em capítulo próprio, que a limitação da propriedade por um "controle jurídico público" se mostra absolutamente insuficiente. ${ }^{137}$

Desta forma, o que é comum não pode permanecer em nenhuma destas instâncias, seja privada ou pública, mas ser objeto de uma alternativa antagonista a este binômio: o que é comum deve ser reapropriado sem intermediações, deve ser gerido democraticamente pela multidão. Trata-se de pensar, como afirma Mendes, "em uma lógica de compartilhamento que dispensa a lógica da exclusividade da propriedade, bem como reconheça a esfera da cooperação social a partir de um horizonte de liberdade e autogoverno". 138

A partir do reconhecimento daquilo que apresentamos até aqui, uma nova noção de "comum" surge: uma noção do comum que foge da corporalidade, que não se restringe aos "bens comuns" mas que reconhece "a produção do comum" como esta "potência" de contínua transformação em toda a sua diversidade: afetos, relações sociais, formas de vida, formas de cooperação, de expressões e de comunicação. Transcrevemos aqui passagem de Ugo Mattei que bem trata sobre o tema:

\footnotetext{
${ }^{136}$ F. MENDES, Alexandre. Op.cit. p.161-164.

${ }^{137}$ F. MENDES, Alexandre. Op.cit. p.164-165.

${ }^{138}$ F. MENDES, Alexandre. Op.cit. p.166.
} 
"O comum se encontra para além da oposição reducionista "sujeito-objeto", que produziu a mercantilização deste último. O comum, contrariamente aos bens privados e públicos, não é uma mercadoria e não pode ser exprimido em termos de posse [possession]; o comum exprime uma relação qualitativa. Seria redutor dizer que nós possuímos um bem comum. É preciso levar em conta o fato de que nós fazemos parte do comum, na medida em que fazemos parte de um meio ambiente, de um ecossistema urbano ou rural." 139

Como dissemos anteriormente, é neste novo terreno em que a exploração engendrada pela "acumulação primitiva" do capital vai atuar, inviabilizando as próprias condições de produção do comum ao reduzir tudo há uma equivalência (como havia tratado Nancy) e a relações de competitividade (como havia tratado De Angelis), "assaltando a própria cooperação social, e transformando a riqueza socialmente produzida em "mais valia", que adquire status de exclusividade pelas cercas farpadas da "propriedade privada e pública" $" 140$.

Passamos assim ao caminho inverso do estabelecido pela lógica da propriedade privada, que partiu da ideia de interiorizar os poderes na figura do sujeito, reduzindo-o a um "indivíduo proprietário", para uma desinteriorização que coloca o sujeito no âmbito de uma "existência compartilhada" e leva em conta as potencialidades da "produção social". A superação desta "mentalidade proprietária", analogia também feita por Mendes com relação ao já tratado trabalho de Paolo Grossi, coloca-nos mais próximos do final de nossa caminhada.

Cristalizam-se aqui as relações existentes entre o "trabalho vivo", "biopolítica", "multidão" e "comum". O trabalho de Mendes tem por mérito ultrapassar o "comum" e o seu reducionismo a "relações sociais" ou "bens comuns", e colocar o "trabalho vivo" e a "multidão" como verdadeiras potências produtoras de subjetividades que irão se opor a "subjetivação proprietária".

Mendes traz portanto o conceito de "multidão de pobres", tratado por

139 F. MENDES, Alexandre. Op.cit. p.166. Apud. Mattei, Ugo. L'etat, le marché et quelques questions préliminaires à propos du commun (2011), sem página, tradução do autor.

140 F. MENDES, Alexandre. Op.cit. p.167. 
Negri e Hardt em Commonwealth, para designar justamente essa potência que reside no reconhecimento de que é no "trabalho livre", livre das amarras dos meios de produção capitalista e erigindo-se sobre as bases da "produção social", que encontra-se a infinita "potência dos pobres" como verdadeira força antagônica à subjetivação proprietária. A "multidão dos pobres" permanece como o centro do projeto de transformação revolucionária, pois adquire "condições para retomar o processo que liga a liberdade política à emancipação econômica."141

É justamente esta nova "classe perigosa", a "multidão de pobres", que carregam em si a verdadeira potência para mudar as regras do jogo. Enquanto a multidão surge como ator central, o comum surge como o novo campo de disputa de uma reapropriação da riqueza social que vem sido constantemente saqueada pelo capital através do tempo: a disputa pelo comum surge como o novo caminho que nos levará a emancipação. Como já havia intuído De Angelis:

"the expropriators must be expropriated so that we can rebuild our lives through new forms of sociality."142

\footnotetext{
${ }^{141}$ F. MENDES, Alexandre. Op.cit. p.170.

${ }^{142}$ DE ANGELIS, Massimo. Op.cit. p.7.
} 


\section{Conclusão.}

A nossa longa jornada termina com uma conquista: a de uma alternativa palpável a um conceito de propriedade que historicamente nos foi imposto. Se já pressupúnhamos a dificuldade de nosso trajeto, não fomos decepcionados. Somos forçados a reconhecer a amplitude do tema, e consequentemente nossa limitação em abranger de forma exaustiva todos os assuntos abordados.

Após estudar o conceito de propriedade, suas origens históricas e suas transformações, paulatinamente as questões relativas à propriedade foram surgindo de maneira mais clara; o presente trabalho foi também construído a partir desta perspectiva, de um amadurecimento, de descobertas e de sentimentos.

Constatamos que para oferecer uma alternativa ao conceito de propriedade, deveríamos ir muito além de um simples conceito que the fosse contraposto. A propriedade não se restringe a um conceito, pois restringi-la a um conceito é justamente retroceder ao ponto de onde viemos: seria delimitá-la, quantificá-la e torná-la apropriável.

A grande dificuldade reside no fato de compreender a "propriedade para além da propriedade". Estabelecemos aqui nosso próprio antagonismo: para pensar em um futuro, em uma alternativa, tivemos que retornar àquilo que é verdadeiramente essencial.

Reconhecer a "riqueza social", a "produção de subjetividades", a diversidade, a criatividade como as verdadeiras riquezas, põe em evidencia os novos horizontes de luta contra o processo "apropriatório" engendrado pelo capitalismo, processo este que tente cada vez mais a nos desumanizar.

Reconhecer no "comum", na nossa multiplicidade, nas relações sociais, nas forças produtivas, no trabalho vivo e nas relações afetivas as verdadeiras potencialidades de transformação é um caminho doloroso, mas libertador. Trata-se de compreender a essencialidade para além da propriedade. É um processo doloroso sim, pois ao mesmo tempo em que 
coloca uma luz no caminho para liberdade, dá-nos igualmente uma responsabilidade: a de reconhecer que não pode haver intermediários entre nós e a nossa liberdade, a de que nós somos a centralidade daquilo que está em disputa.

Caminharmos para a nossa liberdade é termos consciência daquilo que está em disputa, é livrarmo-nos daquilo que nos escraviza, ter consciência de nossa potencialidade e viver pelo que acreditamos: um mundo mais justo, mais democrático e mais humano. 


\section{Bibliografia:}

BANDEIRA DE MELLO, Celso Antônio. Curso de Direito Administrativo $27^{\mathrm{a}}$ Edição, 2010. Editora Malheiros, São Paulo.

DE ANGELIS, Massimo. "Reflections on alternatives, commons and communities or building a new world from the bottom up". In: The Commoner $\mathrm{n}^{\circ} 6$ Winter 2003. Disponível em: www.commoner.org.uk/deangelis06.doc

FABIANO MENDES, Alexandre. "Para além da "Tragédia do Comum": conflito produção de subjetividade no capitalismo contemporâneo". Tese de Doutorado. Rio de Janeiro, Universidade do Estado do Rio de Janeiro UERJ - Centro de Ciências Sociais e Faculdade de Direito, 2012.

FARIAS, Cristiano Chaves de; ROSENVALD, Nelson. Direito Reais. 6. ${ }^{\mathrm{a}}$ ed. Rio de Janeiro: Editora Lúmen Júris, 2010.

GASSEN, Valcir. Fundamentos da História do Direito, Coordenador Antônio Carlos Wolkmer, editora Del Rey, Belo Horizonte 2009, $4^{\text {a }}$ edição.

GOMES, Orlando. Direitos Reais. 20. ${ }^{\mathrm{a}}$ ed. . Rio de Janeiro: Forense, 2010.

GROSSI, Paolo. História da Propriedade e outros ensaios. Editora Renovar. Rio de Janeiro, 2006.

HARDT, Michael; NEGRI, Antonio. “Commonwealth”, The Belknap Press of Harvard University Press, Cambridge, Massachusetts, 2009.

HARDT, Michael; NEGRI, Antonio. "Empire”, Harvard University Press, Cambridge, Massachusetts/London, England, 2000. 
LUCARELLI, Alberto. "Au sein de la Constitution et au-delà de la Constitution. A la recherche de nouvelles dimensions de droit public : participation et biens comuns", Université de Naples, Federico II, sem data. Disponívelem:

http://seminaire.samizdat.net/IMG/pdf/contrbution_albertolucarelli.pdf acessado em 20/10/2013.

MATTEI, Ugo. "Rendre inaliénables les biens comuns" Le Monde Diplomatique, dezembro 2011. Disponível em http://www.mondediplomatique.fr/2011/12/MATTEI/47058, acessado em 20/10/2013.

PEREIRA, Caio Mário da Silva. Instituições de Direito Civil. Direitos Reais, IV. 21. ${ }^{\text {a }}$ ed. Rio de Janeiro: Forense, 2013.

PILATI, José. Conceito e Classificação da propriedade na pósmodernidade: a era das propriedades especiais. Trabalho defendido no II Encontro Temático do Projeto Casadinho UFC/UFSC, ampliado e transformado em artigo. In: Revista Sequiência, no 59, p. 89-119, dez. 2009, p 31 .

PEDERSEN, J.Martin, "Property, Commoning and the Politics of Free Software", In: The Commoner $\mathrm{n}^{\circ} 14$, Winter 2010. Disponível em : http://www.commoner.org.uk/?p=107 acessado em 20/10/2013.

SILVA, José Afonso da. Curso de Direito Constitucional Positivo. 27 edição, Editora Malheiros, São Paulo, 2006,.p. 275. 